\title{
The decline of Dayak political movements (1960-1971)
}

As discussed previously, the first Dayak political party supported the Dutch colonials, and Dayaks and their party were some of the staunchest supporters of DIKB, a state created by the Dutch. After temporarily disappearing from provincial politics after DIKB was dissolved in 1950, they recovered quickly following PD's wins in the 1955 and 1958 elections. The number of Dayaks finding positions in the bureaucracy started to increase, although they still represented a very small percentage of the civil service. Dayaks were appointed as executive heads in several districts, and a Dayak was appointed governor of West Kalimantan. This golden era for Dayak politics lasted for a little more than ten years (19551966). After 1966, however, Dayak political influence declined rapidly. From the end of the 1950s to the mid-1960s, Dayak politics underwent various life-saving processes, from $\mathrm{PD}$ to Partindo, and from Partindo to IPKI. Each process weakened Dayak politics even further.

\section{BREAK-UP OF DAYAK POLITICS}

At the end of the 1950s, Indonesia faced several political uncertainties. Liberal democracy did not provide stability to the nation because parliamentary governments failed to resolve the struggles between political parties. After years of deliberation, the Konstituante was still unable to reach compromise on the new constitution. Meanwhile, insurgencies were on the rise in some regions. Soekarno's solution was to introduce the Guided Democracy system, in which the President became the power centre of Indonesian politics.

Under Guided Democracy, a new regulation, Penpres 7/1959, was introduced to regulate political parties, curb growing regionalism, and 
limit foreign intervention in Indonesian politics. Under this regulation political parties could receive no foreign funding without government permission, and no foreigner could be a member of a political party. More importantly for local political parties, this regulation required each political party to have branches in at least a quarter of the provinces. $\mathrm{PD}$ was one of many regional parties whose constituents were based in certain areas and who could not fulfil this requirement.

PD's four branches were all in Kalimantan. ${ }^{1}$ Within the other three Kalimantan provinces, only Central Kalimantan was strong enough in the 1958 general election to win enough votes to place a few representatives in the local parliament. ${ }^{2}$ Various sources claimed that there were efforts to set up new branches in Yogyakarta and other cities, where Dayaks were studying, but the number of Dayaks in these cities was very small. Dayak students were not united politically, especially those from outside West Kalimantan. Eventually, all efforts to set up additional branches failed. ${ }^{3}$

The only way to save the party was to merge into a larger national party. Internal party deliberations resulted in a decision that the new party should have a nationalist and not a sectarian (in this case, not religious) platform. This requirement automatically excluded the Catholic Party, a party favoured by Palaunsoeka, one of PD top leaders. Three other nationalist parties fulfilled these requirements: PNI, IPKI, and Partindo. PNI was a party with a history dating back to 1927; it had been established by Soekarno, who was a student at that time. IPKI was a relatively new party founded in 1954 by military veterans. Partindo was the newest party, established only in $1958 .{ }^{4}$ In 1959, the leaders of West Kalimantan PNI were S.H. Marpaung and Dr Soedarso, neither of whom a native of West Kalimantan. West Kalimantan IPKI was led by Ibrahim Saleh and Tan Husni Abdullah, both of whom were Malay. Partindo, as a newcomer in national politics, still had no office in West Kalimantan.

\footnotetext{
1 David Doengo, 'Partai Persatuan Daya (PD) dan kelanjutannya', 1969, in: Private collection, Pontianak.

$2 \quad$ PD obtained three seats in the Central Kalimantan provincial DPRD. At the district level, only in Kapuas district did PD gain a significant number of seats (five) ('Daftar angka hasil pemilihan DPRD 1958', 1958, in: Collection of Robert Cribb, Canberra). The majority of Dayak votes of Central and East Kalimantan went to nationalist and Christian political parties.

$3 \quad$ Interviews with $\mathrm{Kls}$ and Ttg.

4 Partindo was founded on 29 April 1931 after the colonial government banned PNI, but fell into obscurity.
} 
PD leaders realized that they would lose their dominance if they merged with PNI as PNI was already well established in West Kalimantan. Merging with the smaller IPKI probably required fewer compromises, but that party had few prospects. IPKI's support came mainly from military veterans and their sympathizers. The next alternative was the newly established Partindo that had grown rapidly at the national level because of the personal links its leaders had with Soekarno, and its leftist leaning suited the political atmosphere. ${ }^{5}$ Partindo rose quickly to national prominence and by 1964 it already had several cabinet ministers. ${ }^{6}$ It claimed to be the purest adherent of Marhaenism, a very popular political concept in the 1960s. ${ }^{7}$

The leadership of PD finally chose to merge with Partindo. ${ }^{8}$ One obvious reason for this decision was that merging with Partindo required the smallest political sacrifice; PD could preserve its structure and personnel because Partindo still had no presence in West Kalimantan. ${ }^{9}$ In fact, as far as West Kalimantan was concerned, the merger would be a mere change of party name, from 'PD' to 'Partindo'. With a PD official letter signed by Saijan Tiong, deputy general chairman of PD, all PD branches, affiliates and leaders automatically became Partindo branches, affiliates and leaders on the day of the merger, 15 August 1961. ${ }^{10}$ Another reason was that Partindo had good political prospects, as explained above.

PD's merger with Partindo had several political consequences: it signalled the end of Dayak political unity, inaugurated a more inclusive

\footnotetext{
5 Asmara Hadi, the general chairman of Partindo, was a son-in-law of Soekarno. Partindo chairman, Winoto Danu Asmoro, was Chief Assistant to the President. Other Partindo leaders such as A.M. Hanafi, Armunanto, and Winarno Danuatmodjo were close confidants of Soekarno (Oei 1995:96; Rocamora 1975:233).

6 They were Sutomo Martopradoto, Oei Tjoe Tat, Adisumarto and Armunanto (Crouch 1978:195). Support for Partindo was also on the rise in some regions; Governor Oevaang Oeray of West Kalimantan and Governor Sutedja of Bali were members/sympathizers of the party. All Dayak bupati in West Kalimantan, bupati of Buleleng, and Tana Toraja were members or sympathizers of Partindo. See for example Bigalke 2005:416; Robinson 1998a:376.

$7 \quad$ Marhaenism was an ideology articulated by President Soekarno to describe the Indonesian version of Marxism.

8 PD chapters in South and Central Kalimantan seemed to have merged into PNI (Rocamora 1970:379).

9 David Doengo, 'Partai Persatuan Daya (PD) dan kelanjutannya', 1969, in: Private collection, Pontianak.

1o Saijan, 'Pernjataan peleburan Partay Persatuan Daya kedalam Partai Indonesia (Partindo)', 1961, in: Collection of St. Ngo Lahay, Pontianak.
} 
political approach, and caused a rapid penetration of national politics into Dayak politics, including leftist influence.

\section{PARTINDO VERSUS PK}

Although officially all PD branches were instructed to merge with Partindo, a number of individuals chose not to join. The majority of this small faction led by Palaunsoeka joined the Partai Katolik (Catholic Party, PK). ${ }^{11}$ Prior to that, PK was a very small political party in the province. In the 1955 election, it obtained only 2,505 votes, or less than 0.6 per cent of the total provincial votes, and gained only one seat in the provincial DPRD. The very low number of votes it received in interior districts indicated that most Dayaks did not support the party. ${ }^{12}$

Palaunsoeka's preference for PK reflected the fact that he was a devout Catholic, but his decision could also have been influenced by his long-standing political ties with the party-- close ties that started at the end of 1940s when as a member of national parliament, Palaunsoeka chose to affiliate with the PK Faction. This link led to closer cooperation between PD and PK in West Kalimantan during the 1958 local election, in which members of PK campaigned on the PD slate. Members of PK such as Lim Bak Meng (provincial level) and Paulus Tjong Bun On (Pontianak City) were listed in the legislature as PD representatives. ${ }^{13}$ The Communist leanings within the Partindo leadership might also have contributed to Palaunsoeka's decision to join PK (Davidson 2008:46). Palaunsoeka's followers argued that the merger with Partindo would drive the Dayaks toward Communism.

Palaunsoeka's role in PD surpassed Oeray's. Palaunsoeka had been the founder of DIA, the predecessor of PD. He was the deputy chairman of the party in 1947, became one of the party chairmen in 1951, and then served as its general chairman until the party was defunct. However,

1 He then became the general chairman of West Kalimantan PK, and later a member of the Central Leadership Board (DPP) of PK at the national level. Before the 1955 election, the party provincial chapter was headed by a Chinese, Lim Bak Meng, while the Singkawang chapter was headed by a Dayak, Agustinus Lanjo. According to one memoir, West Kalimantan PK was established by Lim Bak Meng in 1952 (Lim Bak Meng, 'Riwayat perjuangan', 1977, Lim Bak Meng, 'Riwayat perjuangan', 1978, in: Private collection, Pontianak).

12 Its highest number of votes was obtained in coastal regions: Sambas district with 1,001 votes, followed by Pontianak City with 744, and Pontianak district 532 votes. Other districts received negligible results between 28 and 75 votes each (Alfian 1971:135).

13 Interview with Bln. 
he still failed to persuade a majority of the PD leadership to join PK. Davidson argues that Palaunsoeka's years in Jakarta as a member of parliament had prevented him from having continuous contact with the local party leaders; as a consequence, he lost some of his personal influence within the PD leadership (Davidson 2002:108). On the other hand, unlike Palaunsoeka, Oeray was based in West Kalimantan and therefore was able to maintain his influence within the party (Davidson 2002: 108). Oeray was general chairman in 1947 for only a short period and then became advisor to the party. However, his leadership during the first two years after WWII and his position in the executive council of DIKB had made him better known than Palaunsoeka. As the governor, he had influence over all important Dayak civil servants and members of the legislature, who were apparently also leaders of PD. One source also notes that Oeray was a more effective communicator capable of attracting larger audiences compared to the more bookish Palaunsoeka (Davidson 2002:108, 2008:41).

The rivalries between Oeray and Palaunsoeka and their respective followers began at the end of the 1950s and lasted through the first two decades of the New Order period. Initially Oeray accused Palaunsoeka of being a traitor because he had converted a PD seat in the National Parliament into a PK faction seat without consulting the party. ${ }^{14}$ Palaunsoeka accused Oeray of illegally merging the party with Partindo, because it was done without his approval. As general chairman Palaunsoeka was apparently absent from the meeting that approved the merger. ${ }^{15}$ After the leadership split, Governor Oeray excluded members of PK from important executive and legislative appointments. All members of provincial legislatures from the former PD who supported Palaunsoeka and joined PK, such as Lim Bak Meng, M. Andjioe, and Massoeka Djanting, were replaced. On several occasions, Oeray was also very critical of the Church authorities because generally they were

14 PD cooperation with PK at the National Assembly before 1955 seems to have been a party decision, as besides Palaunsoeka, Djelani (the chairman of PD), also joined the PK Faction. However, Palaunsoeka's continuing membership in the PK Faction after the 1955 election could have been a result of his individual decision or preference because by this time PD already had established its own faction in the Konstituante. There was no reason PD was not able to form its own faction at the National Parliament because there were at least three other political parties. Most only had one seat each yet had their own factions in the parliament (Parlaungan 1956:34). After the PD merger with Partindo, PD's seat at the National Parliament became the seat of Partai Katolik.

${ }_{15}$ Interviews with Bln and Syk. 
PK supporters. ${ }^{16}$ Partindo's acting director of the Civil Service Institute (APDN) allegedly prevented many candidates with PK background from joining the academy. ${ }^{17}$ Partindo supporters were also behind moves to thwart Palaunsoeka's bid for the governorship in 1967, after Oeray was removed from power. ${ }^{18}$ On the other hand, PK members also opposed Partindo and Oeray's leadership. PK had demanded Oeray's resignation from early 1965, long before similar but more serious demonstrations were staged. In March 1965, together with other political parties such as PNI and Parkindo (a Christian Party), PK signed a resolution urging Soekarno to remove Oevaang Oeray from the governorship. In the letter, they accused Oeray of stirring up hatred between the native and non-native populations. ${ }^{19}$ During the pogrom against the Chinese in 1967, which will be discussed later, Palaunsoeka criticized Oeray and his supporters for being the instigators of the frenzied Dayak mobilization (Pembangunan, 16-11-1967; Kompas, 20-11-1967).

\section{MORE INCLUSIVE POLITICS}

PD seems to have embraced a more conciliatory approach toward other political parties since the mid-1950s. However, by and large PD was still an ethnic party. PD was Persatuan Dayak and its statutes clearly stated that PD was only for the Dayaks. Non-Dayaks who had genuine concerns for the Dayaks could only be extra-ordinary members. ${ }^{20}$

Partindo was far more inclusive than PD, although the majority of leaders and members of West Kalimantan Partindo were Dayaks. Unlike PD, Partindo was a nationalist party with open membership, and it had

16 Davidson 2002:108, 2008:46; Van Hulten 1992. Another reason for Oeray's criticism of the Church was that its top leadership was always too much under the power and direction of Dutch priests (interview with Smd).

${ }_{7}$ Interview with Lnj. Although the Director rejected the accusation, suspicions among the PK sympathizers about the exclusion were strong (interviews with Ttg and Lnj).

18 Some Partindo members went to Jakarta to assure the central government that Dayaks would not act against the decision to install a non-Dayak governor. This neutralized earlier demands from some other Dayaks for a Dayak governor (interview with Mgn).

19 Abi Hurairah Fattah (PNI), Chris F. Hetharia (Parkindo), P.F. Soedjimin (PK), Ismail Hamzah (Angkatan 45), 'Surat resolusi untuk meretul Gubernur Oevang Oeray', 1965, in: Collection of St. Ngo Lahay, Pontianak. The text is not quite clear whether the native (suku penduduk ashi) referred solely to Dayaks.

${ }_{20}$ 'Anggaran dasar Partai Persatuan Daya', in: Kongres ke III Partai Persatuan Daya, 1954, p. 9, in: Private collection, Sanggau. Lim Bak Meng, a prominent Chinese during the 1950s and 1960s, claimed that he had belonged to PD since 1947 (Lim Bak Meng, 'Riwayat perjuangan', 1978, in: Private collection, Pontianak). 
a growing number of non-Dayaks in top leadership positions. After a party congress in 1964, West Kalimantan Partindo had four non-Dayaks, Ajub Akri, Slamet A.H., P. Susilo and Djufri Saleh, appointed to top leadership positions, while the Dayaks were represented by Ngo Lahay (as party chairman), Victor Oendoen and Hugo Mungok (Bintang Timur, 7-10-1964). Some non-Dayaks represented Partindo in the DPRD, such as Slamet A.H. and Ng Eng Soe at provincial level; Djufri Saleh, and Tan Bu Hiap ${ }^{21}$ in Pontianak City; Lim Soe Seng, and H. Minun Abdul Wahid in Pontianak district; and Tjong Hian Kong in Sambas. ${ }^{22}$ Pluralism within the party leadership would naturally prevent the party from taking an exclusively ethnic approach.

Compared to PD, Partindo sent fewer members to the DPRD. Regulation Penpres 4/1960 (June 1960) forced political parties, including Partindo, to give up some of their seats in order to accommodate the newly created functional groups (golongan karya) in the legislatures. ${ }^{23}$ Partindo also lost some of its DPD seats because of the implementation of the concept of nationalism-religion-Communism (Nasakom). This concept, which was introduced in 1960 by Soekarno (Mackie 1974:86), required the presence of each of these elements in every important government body. As Partindo had a larger number of seats in the DPD compared to other political parties, it was required to relinquish some of its seats to the Communist Party (PKI). At the provincial level, Dayak DPD members were reduced from two to one. Similar changes occurred at the district level. Partindo, therefore, needed more compromise and

21 Tan Bu Hiap had an affiliation with Partindo and PKI, but decided to retain his PKI membership when he was asked to choose (interview with Djf). When he resigned from Partindo in 1963, his position in the DPRD was given to Djufri Saleh ('Laporan kerdja tahun 1963', 1964, appendix, in: Library of West Kalimantan Governor's Office, Pontianak).

22 'Laporan kerdja tahun 1963', 1964, pp. 8-15, in: Library of West Kalimantan Governor's Office, Pontianak. Motives for non-Dayaks to want to join Partindo varied; a few joined because their Dayak superiors were Partindo leaders (interviews with Djf and Lnd). Strategically crafted leadership, such as Partindo in Sambas and Pontianak districts with their Senganan leaders (Dayak Muslims), attracted Muslim Malays to the party (interview with Idr).

23 After the Presidential decree in July 1959, the President moved to concentrate power in his own hands. In March 1960, the President dissolved the elected national legislature and created a new 'mutual cooperation' legislature (DPR-GR). In this new legislature, more than half (54 per cent) of members came from functional groups, all of whom were appointed by the President. The functional groups were introduced into the legislature in order to accommodate wider interests and most importantly to balance the role of political parties, which had destabilized the political system prior to the Guided Democracy, as can be seen from incessant cabinet reshuffles (Ricklefs 2001:324-5; Tas 1974:270-1). Members of functional groups were individuals or members of professional organizations that had no affiliation with any political party. 
cooperation with other political parties in many issues which further made the party more inclusive in its outlook.

\begin{tabular}{|c|c|c|c|c|c|c|c|c|c|c|c|}
\hline \multirow{2}{*}{\multicolumn{2}{|c|}{$\begin{array}{l}\text { Province/ } \\
\text { District }\end{array}$}} & \multicolumn{2}{|c|}{$\begin{array}{c}\text { PD/ } \\
\text { Partindo }\end{array}$} & \multicolumn{2}{|c|}{ PNI } & \multicolumn{2}{|c|}{ NU } & \multicolumn{2}{|c|}{ PKI } & \multicolumn{2}{|c|}{ IPKI } \\
\hline & & 1958 & 1963 & 1958 & 1963 & 1958 & 1963 & 1958 & 1963 & 1958 & 1963 \\
\hline \multicolumn{2}{|c|}{$\begin{array}{l}\text { West } \\
\text { Kalimantan }\end{array}$} & 12 & 7 & 4 & 3 & 2 & 3 & 1 & 1 & 1 & 1 \\
\hline \multirow{7}{*}{ 苞 } & $\begin{array}{l}\text { Pontianak } \\
\text { City }\end{array}$ & 2 & 2 & 1 & 1 & 2 & 2 & 2 & 1 & 1 & 1 \\
\hline & Pontianak & 13 & 8 & 3 & 2 & 4 & 3 & 1 & 1 & 1 & 1 \\
\hline & Sambas & 5 & 5 & 4 & 3 & 1 & 4 & 2 & 2 & & \\
\hline & Sanggau & 12 & 7 & 3 & 2 & 2 & & 1 & & & \\
\hline & Sintang & 9 & 6 & 3 & 2 & 1 & & & & & \\
\hline & $\begin{array}{l}\text { Kapuas } \\
\text { Hulu }\end{array}$ & 7 & 5 & 2 & 2 & & & & & & \\
\hline & Ketapang & 4 & 3 & 3 & 2 & & 2 & & & & \\
\hline \multicolumn{2}{|c|}{ Total } & 64 & 43 & 23 & 17 & 12 & 14 & 7 & 5 & 3 & 3 \\
\hline
\end{tabular}

Table 5.1 Number of seats in parliament held by selected parties $(1958,1963)$

Source: 'Daftar angka hasil pemilihan DPRD 1958', 1958, in: Collection of Robert Cribb, Canberra; 'Laporan kerdja tahun 1963', 1964, pp. 8-15, in: Library of West Kalimantan Governor's Office, Pontianak.

West Kalimantan Partindo also became more inclusive because of the deeper influence of national politics on the province. The Dwikora campaign against Malaysia between 1963 and 1966 brought the relatively calm West Kalimantan to the forefront of national politics. This campaign required political repositioning and adjustment of all elements in West Kalimantan and brought together many political parties, some of which had been alienated from each other. National Partindo, as one of the most radical political parties and one of the main supporters of the campaign, drove the West Kalimantan Partindo to take part in the campaign. On many occasions Dayaks were mobilized to support the Dwikora campaign (Bebas, 30-7, 9-10, and 7-11-1963). This campaign nationalized the exclusive Dayaks and incorporated them more into national politics. 


\section{PARTINDO AND LEFTIST POLITICS}

Since its inception, West Kalimantan Partindo had been plagued with accusations of being a Communist party. The accusation was rejected by its leaders, many of whom were Catholics, as baseless. Upon receiving the party chairmanship in August 1962, Ngo Lahay vowed to take action against any atheists within the party. ${ }^{24}$ On 24 March 1962, West Kalimantan Partindo protested and rejected the installation of a proCommunist leadership in the party's national headquarters. ${ }^{25}$

Anti-left movements within West Kalimantan Partindo seemed to wither as national politics leaned left and as the Partindo governor (Oevaang Oeray) tried to emulate Soekarno, who was drawing closer to the left. ${ }^{26}$ Like the party at the national level, West Kalimantan Partindo developed close relations with Baperki (Oei 1995:98). This relationship is important to mention because at a later stage many Partindo leaders were detained because of their links with Baperki.

Baperki was a Chinese organization aimed at integrating the Chinese into the Indonesian community. Its national leader, Siauw Giok Tjhan, was known to have close relations with the PKI. West Kalimantan Baperki's leftism was exhibited by some of their members, such as Pheng Zen Nen, who was also an important figure in PKI. Baperki's chairman, Liem Kiong Wan was head of HSI, an affiliate of PKI. ${ }^{27}$ Some teachers in Baperki schools who were recruited from Java turned out to be volunteers from Pemuda Rakyat, another PKI affiliate. ${ }^{28}$ There was also a strong Chinese presence in PKI cadre lists (Hui 2007:132).

West Kalimantan Baperki, contrary to general belief, was a small organization with limited support from the Chinese population in the province. Most West Kalimantan Chinese, who did not have Indonesian

\footnotetext{
${ }_{24}$ Stephanus Ngo Lahay, 'Pidatoku pada penerimaan pimpinan Partindo Kalimantan Barat', 1962, in: Collection of St. Ngo Lahay, Pontianak.

25 Bintang Timur, 28-12-1961; 'Pernyataan', 1962, in: Collection of St. Ngo Lahay, Pontianak.

26 National politics from the beginning of the 1960s had been characterized by the competition of two opposing political powers - the PKI and its groups versus the army, which was supported by anti-PKI political parties - and Soekarno who tried to manage them. However, closer to the end of his rule, Soekarno had grown increasingly close to the left (Crouch 1978:51-68; Feith 1964b; Ricklefs 2001:327-41). ${ }_{27}$ Rachman et al. 1970:219, 225. HSI (Himpunan Sarjana Indonesia) was a scholar league established in early 1962 and linked to PKI (Feith 1964b, 1962).

${ }_{28}$ Interview with Kpg.
} 
citizenship papers, were culturally toto $k^{29}$ and generally uninterested in Indonesian politics. Consequently, they were not attracted to join Baperki, which had an orientation towards Indonesia. ${ }^{30}$ Furthermore almost all the leading figures of West Kalimantan Baperki, such as Liem Kiong Wan, Liem Djoe Siong, and Ong Cin Ciat, were not local Chinese. ${ }^{31}$ They remained aloof from the majority of the local Chinese because of their busy careers, their peranakan attitude and their inability to communicate in local Chinese dialects. ${ }^{32}$ A peranakan Chinese doctor from Java who worked for the government and who was also an official of Baperki in Pontianak district, recollected that he had never had close relations with the local Chinese because to them he was an outsider and a government agent. ${ }^{33}$ There were a few local Chinese who had obtained Indonesian citizenship and had joined Baperki, such as Ng Nyiap Liang, $\mathrm{Ng}$ Eng Soe, and Nio Peng Hian. However, they were still totok in their orientation. ${ }^{34}$ This lack of support from the West Kalimantan Chinese was the main reason why Baperki did not contest the 1955 and 1958 elections in West Kalimantan. ${ }^{35}$

West Kalimantan Baperki differed greatly from its Jakarta headquarters in Jakarta, which was more active and more organized. One member

\footnotetext{
29 The cultural concept of totok (or singkeh) referred to Chinese who were born in Mainland China and continued to live a Chinese lifestyle, particularly their use of the Chinese language. Those who were born in Indonesia and speaking local languages were known as peranakan (Suryadinata 2008:4). This differentiation is insufficient to explain the cultural identity of the Indonesian Chinese as it has become harder to categorize Chinese who were born in Indonesia but who still maintain many aspects of Chinese culture as well as speaking Chinese dialects, such as those in West Kalimantan, Medan, and Bangka.

3o Davidson (2002:129) asserts that the majority of Chinese had hardly any interest in Indonesian politics, since the majority of them were involved more in political developments in mainland China, did not have Indonesian citizenship, and spoke poor Indonesian. A military source noted that 95 per cent of the West Kalimantan Chinese by 1960 did not hold Indonesian citizenship. The percentage of alien Chinese had dropped to only 70 per cent in 1971 . This number is based on the 1971 census which stated that the West Kalimantan population had around 226,216 Chinese, and that the province had 158,805 resident aliens ('Buku petunjuk teritorial daerah Kalimantan Barat', 1972, pp. 54-5, 325-33, in: Library of West Kalimantan Governor's Office, Pontianak). Most aliens in West Kalimantan were undoubtedly Chinese. $3^{1} \quad$ Interview with Een.

$3^{2} \quad$ Language was an important element because many Chinese spoke Chinese dialects and only rudimentary Indonesian. In fact, in some places, they could not speak Indonesian at all. In these places, it was the native population who adapted by speaking Chinese. At that time many Chinese did not consider the Indonesian language as essential in their business activities; therefore they did not bother to learn it (interviews with Kpg, Nes and Asl; 'Buku petunjuk teritorial daerah Kalimantan Barat', 1972, p. 58, in: Library of West Kalimantan Governor's Office, Pontianak).

33 Interview with Kpg.

34 Interview with Nes.

35 This provides an answer to J.A.C. Mackie (1974:350) who was puzzled by the absence of Baperki in West Kalimantan during those two elections. A strong orientation of the West Kalimantan Chinese to their ancestral land between 1945 and 1966 was discussed in Hui (2007:Chapter II).
} 
remembered West Kalimantan Baperki as a simple organization without any formal structure or regular meetings. Until its end it was still an organization based more on volunteering and spontaneity than on careful planning, because its core leaders were all busy professionals. ${ }^{36}$ Its profile depended much on its core leaders' wide social and political contacts. One of its important programs was related to educational activities, such as establishing Baperki schools and inviting teachers from Java. It also planned to establish a university - an ambition that was never realized because of the abortive coup in $1965 .{ }^{37}$ The organization was registered at the governor's office as an educational organization, and not as a political organization. ${ }^{38}$

The political cooperation between the Dayaks and Chinese did not start with Baperki. During the heyday of PD, a few Chinese already represented PD in the local DPRD. In some districts, such as in Sanggau, a few Chinese officials ardently supported the PD. ${ }^{39}$ After the merger with Partindo, the number of Chinese in the legislature representing Partindo slightly increased: Ng Eng Soe, Tan Bu Hiap, Liem Soe Seng, and Tjong Hian Kong were elected into various DPRD. ${ }^{40}$ Cooperation with the Chinese would benefit Partindo financially and politically. Financially, the Chinese controlled much of West Kalimantan's economy, and were

${ }_{36}$ Interview with Kpg. For example, Liem Kiong Wan, its chairman, was a surgeon in the province and worked at the Pontianak General Hospital. Almost everyone of importance at that time knew him. Liem Djoe Siong was another doctor working at the government hospital in Pontianak. Ong Cin Ciat was a respected lawyer in Pontianak. Kwee Poo Gwan, the Baperki leader of Pontianak district, was the only government doctor in the district.

37 Interviews with Kpg and Nes. At the Baperki conference in August 1965 in Jakarta, West Kalimantan Baperki was praised for its success in opening 42 Baperki schools. According to one source, some teachers from Java were PKI cadres. The source reasoned that there were not so many teachers from Java who wanted to volunteer to become teachers in the jungles of West Kalimantan, except teachers from the Pemuda Rakyat, an affiliate of PKI (interview with Kpg). This keen interest in education was also evident in Baperki activities elsewhere (Ang 2009).

$3^{8}$ Alfonsus Jacobus Tanting Ngo, 'Mohon penyelesaian persoalan dan rehabilitasi atas diri saya', 1978, in: Collection of Alfonsus Jacobus Tanting Ngo, Pontianak.

39 During its campaign in 1958, PD pamphlets in Sanggau district included a Chinese version side by side with the Indonesian version ('Pilihlah Partai Persatuan Daya (P.D.)', 1957, in: Private collection, Sanggau). This support was because of the influence of the Chinese head of the Sanggau civil registry, $\mathrm{Ku}$ Dji Hiun. He was the son of a former local Chinese Affairs official during the Dutch colonial period known as kapitan or laothai. He was allegedly one of the founders of Sanggau Baperki in 1965. After 1965, he safely exited from politics and asked for early retirement (various interviews).

$4^{\circ} \quad$ 'Laporan kerdja tahun 1963', 1964, pp. 8-15, appendix, in: Library of West Kalimantan Governor's Office, Pontianak. 
potential financial contributors for the party's activities. ${ }^{41}$ Politically, as the third largest ethnic group in West Kalimantan, the Chinese were potential supporters (for example by supplying manpower during political rallies and other resources) even though they were resident aliens.

Personal contacts between the leaders of West Kalimantan Partindo and Baperki may have begun in the early 1960s. At the national level, since the beginning of 1960 some Baperki leaders had already become leaders in Partindo, and vice versa (Oei 1995:90, 96). Formal cooperation between the two organizations in West Kalimantan was unlikely to have been established before 1964. An official invitation to Ngo Lahay, chairman of Partindo, to join Baperki was not issued until August 1965. ${ }^{42}$ Some Dayaks in Singkawang and Sanggau who became leaders of Baperki in their respective locales also claimed that the timing of their joining the organization was quite close to the coup. ${ }^{43}$ According to one Partindo official, the chairman of West Kalimantan Baperki, Liem Kiong Wan, was made one of the deputy chairmen of Partindo. Ngo Lahay and H.G. Mihing, two Partindo officials, also appeared in the provincial Baperki structure. ${ }^{44}$ In some areas, such as Singkawang and Sanggau, Partindo leaders led the setting up of Baperki. There West Kalimantan Partindo aimed to penetrate and seize the leadership of Baperki in Kalimantan in order to block the PKI's influence on the schools of the Indonesian-Chinese. ${ }^{45}$ As it was party policy, many members of Partindo at the district level were automatically included in Baperki, sometimes without their knowledge. ${ }^{46}$

Partindo's leftist links were not limited to its association with Baperki. Partindo encouraged its members to join HSI, which at the national level was known as an affiliate of PKI. However, according to one figure within West Kalimantan HSI, West Kalimantan PKI did not list HSI as

\footnotetext{
${ }^{4}$ One source mentions his close relations with the Chinese in the 1950s because of associations in setting up businesses (interview with Lnj). Lim Bak Meng helped PD open a small trading company to raise funds for PD congresses (Davidson 2002:101).

$4^{2}$ Lahay's letter to the chairman of West Kalimantan Baperki, declining the invitation to join Baperki, was dated 16 August 1965. Lahay referred to the invitation as 'yesterday's conversation' (St. Ngo Lahay, 'Tidak bersedia duduk didalam Baperki', 1965, in: Collection of St. Ngo Lahay, Pontianak). However, two sources mentioned that Lahay later sat in Baperki leadership ranks (interviews with Bln and Mgk).

43 Interviews with Ssg and Wbd.

44 Interviews with Mgk and Bln.

45 Stephanus Ngo Lahay, 'Pernjataan hubungan Partindo dan Baperki', 1969, in: Collection of St. Ngo Lahay, Pontianak.

$4^{6} \quad$ Interviews with Ssg and Djn.
} 
an affiliate. ${ }^{47}$ The source claimed that the reason Partindo allowed its members to join HSI was that Partindo did not have its own university graduates' association, as PNI did with its ISRI. ${ }^{48}$

West Kalimantan Partindo also had some Communist sympathizers. One party top official claimed that Slamet A.H., one of the party deputy chairmen, often made pro-Communist comments. ${ }^{49}$ Slamet was officially expelled from the party in November 1965 after the party discovered that he was a Communist. ${ }^{50}$ Susilo, another of the party deputy chairmen, was also believed to be a Communist. He disappeared sometime after the coup. ${ }^{51}$ Occasionally some Partindo members in the government also purportedly made pro-Communist statements. ${ }^{52}$

\section{POLITICS IN THE EARLY NEW ORDER: PARTINDO AFTER THE COUP}

In the morning of 1 October 1965, a group of army officers and Communist supporters under the command of the chief of the Presidential Guard (Cakrabirawa) kidnapped and murdered several top army generals. However, in less than three days the anti-coup forces under Major General Soeharto were able to overpower rebels in Jakarta. Soeharto and his supporters believed that the movement was a coup attempt by the PKI, and soon led a drive against the Communists. On 12 March 1966, a day after securing the Supersemar ${ }^{53}$ mandate to restore security, Soeharto dissolved the PKI. A week later he arrested fifteen cabinet ministers, an action followed by dismissals and suspensions of suspected government officials, military officers, and regional bureau-

\footnotetext{
47 Other known affiliates of PKI at the national level were Gerakan Wanita Indonesia (Gerwani, Indonesian Women's Movement), Pemuda Rakyat (People's Youth), Sentral Organisasi Buruh Seluruh Indonesia (SOBSI, All Indonesian Trade Unions Federation), Barisan Tani Indonesia (BTI, Indonesian Farmers' Front), and Lembaga Kebudayaan Rakyat (Lekra, League of People's Culture) (Thomas 1981:372).

$4^{8}$ Alfonsus Jacobus Tanting Ngo, 'Mohon penyelesaian persoalan dan rehabilitasi atas diri saya', 1978, p. 2., in: Collection of Alfonsus Jacobus Tanting Ngo, Pontianak.

49 Interview with Mgk.

$5^{\circ}$ St. Ngo Lahay and H.G. Mungok, 'Surat keputusan pemecatan Slamet AH', 1965, in: Collection of St. Ngo Lahay, Pontianak.

$5^{1} \quad$ Interview with Smd.

$5^{2} \quad$ Interviews with Djg, Mgk and Syk.

53 Supersemar was a short form of Surat Perintah Sebelas Maret or the Order of 11 March, the date when the mandate was issued by President Soekarno.
} 
crats (Crouch 1978:195). Many who had links with the PKI and its affiliates were arrested, and in parts of Java, Bali, and Sumatra they were killed en masse. Soekarno was accused of knowing about the coup plan but not preventing it from happening and being reluctant to incriminate PKI. He was finally stripped of power in 1967 after failing to reverse the trend to unseat him.

The political tide after the coup changed, rapidly moving away from the left. Political parties that had a leftist and pro-Soekarno leaning were the main targets of the incoming regime. Partindo was automatically a target because it had close relations with Soekarno and aligned with the leftist elements, such as PKI, pro-left faction of PNI (known as Asu-PNI), Baperki, and HSI. ${ }^{54}$ Partindo had a close relationship with PKI and PNI because they shared a similar nationalist left platform. ${ }^{55}$ Partindo's newspaper, Bintang Timur, was known for its radical and pro-left tone. To make the matter worse, on 4 October 1965, Partindo headquarters published a statement which described the coup movement as just a problem within the army (Alex Dinuth 1997:94). This statement resembled the rebels' claim and was considered pro-coup. The new anti-Communist regime quickly suppressed Partindo and other leftist parties, although the regime never issued a formal instruction to ban Partindo. Many Partindo leaders, including those who held ministerial posts, were arrested (Crouch 1978:195). In mid-1967, the Jakarta military commander prohibited members of Partindo and organizations under it (onderbouw) to attend the legislature meeting. In 1968, the only two members of Partindo in the national legislature were discharged (Seperempat abad DPR 1970:382). In a statement in April 1970, the Minister of Internal Affairs Amir Machmud, singled out Partindo as a leftist party and made its members ineligible to be elected (Van der Kroef 1971:219).

54 USETUPR 20-6-1966. The internal friction within the PNI at the beginning of 1965 resulted in the expulsion from the party on 4 August 1965 of right-wing leaders: Hardi, Mh. Isnaeni, Hadisubeno Sosrowerdojo, Osa Maliki, Karim M. Durjat, Muh Achmat, Sabilal Radjad, and several others. Practically until the establishment of the right-wing PNI on 6 October 1965, the party was under the influence of left-wing leadership. The right-wing PNI had Osa Maliki as chairman, and Usep Ranawidjaja as secretary, and was therefore nicknamed PNI Osa-Usep. The left-wing had Ali Sastroamidjojo as chairman, and Surachman as secretary, and was therefore known as PNI Asu. At a reconciliatory party congress in April 1966 in Bandung, the right wing, with support from the regime, won the leadership (Sjamsuddin 1984b:21-121; Rocamora 1970). Surachman evaded arrest but was killed in an operation against the Communists between June and July 1968 in Blitar, East Java.

55 Van der Kroef (1971:123) described Partindo as 'a left-wing and subsequently PKI-infiltrated offshoot of the PNI'. At the local level, PKI leaders were reported to have assisted Partindo (Rocamora 1975:229, 412). 
In West Kalimantan, Partindo was also accused of being a political partner of the PKI (Rachman et al. 1970:218). One priority of the New Order government was the removal of the Partindo governor, Oevaang Oeray. While his direct ties with Communists were never established, apart from some cursory leftist comments, ${ }^{56}$ Oeray was a Soekarnoist. ${ }^{57}$ After a series of military-instigated student demonstrations to demand his resignation, ${ }^{58}$ Oeray was finally removed from the governorship on 12 July 1966 by a ministerial decision, instead of by presidential decree, ${ }^{59}$ and replaced by Colonel Soemadi, his deputy. ${ }^{60}$

Following Oeray's dismissal came the removal of all Dayaks from district head positions, ${ }^{61}$ and the replacement of many Partindo members of executive governing bodies $(\mathrm{BPH})^{62}$ and other officials whose loyalty to the new regime was unclear. One high-ranking official at the governor's office, who had direct knowledge of the events, gave two reasons: overdue replacement and lack of skills. All district heads had exceeded their terms since all were installed between 1958 and 1960. The govern-

$5^{6}$ Bintang Timur, 28-7-1962. For example, one source close to Oeray mentioned that Oeray believed that the Revolution Council (Dewan Revolusi) formed by Colonel Untung might offer an alternative solution to the country's problems (interview with Smd). Despite such accusation, a foreign office categorized Oeray as not a PKI sympathizer (Poulgrain 1998:262).

57 Both Oeray and Tjilik Riwut, the Dayak governor of Central Kalimantan, were close to Soekarno (Davidson 2002:101-2). According to a senior member of Partindo, before the 1965 coup Oeray was a strong candidate for minister of transmigration, as recommended by Tjilik Riwut (interview with Hsd). Another source very close to Oeray confirmed Oeray and Riwut's closeness to Soekarno, by citing his own experience. Tanting Ngo was about to be nominated to the position of deputy governor of East Kalimantan, by both Oeray and Riwut. These promotions were never realized because of the coup (interview with Ont).

${ }_{5}^{8} \quad$ Interview with Smd.

59 The proper presidential decree for Oeray's removal was issued later on 22 September 1966 (Sejarah perkembangan pemerintahan 1989:17). The use of a ministerial decision showed the regime's desperation to oust him. As in July 1966 Soekarno still exercised most of his formal presidential powers, including the appointment or dismissal of governors. He might not have been willing to sign the removal of his confidants.

6o Before becoming the deputy governor, Soemadi had been a military lawyer at Tanjungpura Regional Military Command in Pontianak until 1964. Soemadi, a Javanese Christian, was born in Yogyakarta in 1923. He was sworn in as the deputy governor on 16 September 1965. On the day of Oeray's dismissal, Soemadi was appointed a caretaker governor. He was appointed as governor on 1 July 1967 and served in that position until 26 September 1972, when he was replaced by Colonel Kadarusno. He then served as general chairman of West Kalimantan Golkar from 1972 until 1984 (interview with Smd; Sejarah perkembangan pemerintahan 1989:17-20).

61 By 1967 all district heads under Oevaang Oeray had been replaced, except one in Ketapang. The surviving district head was Lieutenant Colonel M. Tohir of Ketapang. He was a candidate supported by NU, and was only elected to the office in early September 1965.

62 This executive council was an important body in assisting the governor's daily task. According to regulation Penpres 6/1959, BPH relations with the governor were like relations between the president and state minister (menteri negara). Previously BPH was known as DPD. 
ment also needed to refresh the leadership with more capable persons. ${ }^{63}$ However, the dismissals also could be seen as part of the purge of officials closely associated with the former regime as an opportunity to install pro-New Order officials. The government tactfully described their replacement as 'ending term of service' (selesai masa tugas). Honourable terminations were important to avoid social unrest since all officials were highly charismatic figures among the Dayaks because of their pioneering role in Dayak emancipation since the 1940s. ${ }^{64}$ Oeray and almost all former Dayak district heads with ties to Partindo, however, remained active public servants. Oeray, for example, remained at the provincial office as a senior official until 1971, when he was transferred to Jakarta. He was occasionally given important tasks after being stripped of his governorship. In 1968, for example, he led a team of several district and provincial bureau heads to investigate trade opportunities in Kuching. ${ }^{65}$ On 23 January 1971, he was appointed head of the Regional Screening Committee (PPD), a committee to screen legislature candidates for the 1971 election. ${ }^{66}$ Others such as Bupati Djaoeng and Djelani were appointed advisors to the new district heads, and later were transferred to work at the provincial office. By mid-1968, all district heads were active military officers, except in Sintang and Kapuas Hulu. ${ }^{67}$

Other than those changes, there were no prosecutions of West Kalimantan Partindo members who were not involved with PKI. In the first few years after the coup, their involvement with Baperki was not seen as a factor requiring prosecution. This was contrary to what was happening in other parts of Indonesia where many Baperki and Partindo leaders became the targets of military operations and were often arrested. One possible explanation for this exception was that the military acknowledged the rationale put forward by Partindo leaders for their involvement

\footnotetext{
63 Interview with Smd.

64 Already pro-New Order student demonstrations demanding Oeray's dismissal had provoked counter demonstrations from his Dayak supporters. However, effective and continuous counter-demonstrations were difficult to stage because Pontianak only had a small number of Partindo supporters. Dayak demonstrators who stormed the governor's office to show their support of Oeray travelled a long distance from interior regions (interviews with Smd, Djk, Abs and Ttg). For the same reason, the governor who replaced Oeray had tried to prevent his arrest at the end of the 1960s (interview with Smd).

${ }_{55}$ 'Trade mission Kalimantan Barat ke Kuching dibawah pimpinan JC Oevaang Oeray', 1968, in: Library of West Kalimantan Governor's Office, Pontianak.

66 'Lampiran progress report Gubernur Kepala Daerah Propinsi Kalimantan Barat', 1971, p. 245, in: Library of West Kalimantan Governor's Office, Pontianak.

${ }_{67}$ 'Buku petunjuk teritorial daerah Kalimantan Barat', 1972, pp. 40-8, in: Library of West Kalimantan Governor's Office, Pontianak.
} 
in Baperki. The leaders contended that their involvement in Baperki was to prevent Chinese schools from falling under Communist influence. The Baperki chairman had given some examples, such as the dismissal of several Communist teachers from Baperki schools in Pontianak, and almost no PKI influence was found in Baperki schools under the leadership of Partindo. ${ }^{68}$ In fact, many Dayak Partindo leaders helped the military campaigns uproot Communist insurgents in 1967 as one way to prove that they were not Communists.

The extensive purging in the bureaucracy that took place in some regions in Java did not occur in West Kalimantan. By June 1967, the regime only dismissed 275 employees from the whole West Kalimantan

\begin{tabular}{|l|c|c|}
\hline Offices & Number discharged & Number of employees 1971 \\
\hline Governor's Office & 18 & 612 \\
\hline Kapuas Hulu & 7 & 371 \\
\hline Sintang & 17 & 377 \\
\hline Sanggau & 7 & 354 \\
\hline Pontianak & 30 & 559 \\
\hline Sambas & 34 & 546 \\
\hline Ketapang & 7 & 396 \\
\hline Pontianak City & 7 & 492 \\
\hline Public Works & 45 & 504 \\
\hline Forestry & 13 & 108 \\
\hline Education & 38 & 3,537 \\
\hline Others & 52 & 1,185 \\
\hline Total & 275 & 9,741 \\
\hline
\end{tabular}

Table 5.2 Dismissals of leftists from the West Kalimantan bureaucracy (by June 1967)

Source: 'Progress report Gubernur Kepala Daerah Propinsi Kalimantan Barat periode Djanuari s/d Djuni 1967', 1967, p. 8, Library of West Kalimantan Governor's Office, Pontianak; Varia 1971/23-4:46.

68 Stephanus Ngo Lahay, 'Pernjataan hubungan Partindo dan Baperki', 1969, Soemadi, 'Press release tentang status Partindo', 1970, Achmad Sukarmadidjaja and H. Djilis Tahir, 'Partai IP-KI Kalbar', 1971, in: Collection of St. Ngo Lahay, Pontianak. 
bureaucracy. The highest number of dismissals occurred in Pontianak and Sambas district offices. Purging was apparently more severe in departments or offices that had leaders who were close to the Communists, such as the Public Works Office, where 45 people were dismissed. ${ }^{69}$ One source notes that there were significant number of dismissals in the postal service, which was headed by Slamet A.H., the deputy chairman of Partindo. ${ }^{70}$

West Kalimantan did not experience the extensive leftist prosecutions that happened elsewhere. The relatively small number of Communists in West Kalimantan meant that they were not a threat to the military. Their representatives in DPRD and the BPH were the result of centrally imposed Nasakomization and did not represent its real political force. One reliable government source confirmed this by stating that he even had difficulties between 1964 and 1965 to find PKI figures to be placed in the Sintang and Kapuas Hulu DPRD, as part of Nasakomization. ${ }^{71}$ The political map of West Kalimantan in 1960 estimated PKI to have support of only around 2.5 per cent, a very small figure compared to Partindo's 30 per cent, the Catholic Party's 23 per cent, PNI's 22 per cent, and NU's 21 per cent. PKI also had little political support at the district level except in Pontianak City. After the coup, the military estimated that around 3,500 persons needed to be investigated in the province (Rachman et al. 1970:226).

The lack of popular support meant the Communist Party could not mobilize enough power to intimidate their opponents or to initiate Communist unilateral action (aksi sepihak) in West Kalimantan (Davidson 2002:137). Intimidation and unilateral action in Java that contributed to the enmity behind mass killings seemed to be absent in West

\footnotetext{
69 The head of the provincial Public Works Office was W.S. Silitonga who was also the head of the West Kalimantan HSI (Abdulsalam 1997:74). Together with another HSI figure, Tanting Ngo, he was convicted in October 1965, rehabilitated a month later (Ryacudu, 'Surat keputusan tentang rehabilitasi 2 orang anggauta bekas HIS', 1965, in: Collection of St. Ngo Lahay, Pontianak) but then dismissed from his position in mid-1966 (Abdulsalam 1997:74). Bambang Soemitro, PKI leader before S.A. Sofyan, was once the head of the provincial Public Works Office (Davidson 2002:130). The heads of the offices in Ngabang and Sintang were also linked with Communists (interview with $\mathrm{Mjg}$ ). The strong Communist influence in these offices was confirmed by Van Hulten (1992:66-7).

7o Interview with Bln.

${ }^{71}$ Interview with Smd.
} 
Kalimantan. ${ }^{72}$ Before the time of the mass murder of the Communists taking place in other regions, the West Kalimantan military had already suspended PKI activities on 16 October 1965 (Rachman et al. 1970:225).

The Regional Military Commander Ryacudu and Governor Oeray, the two most powerful men in West Kalimantan at that time, were Soekarno loyalists and allegedly lenient in purging the suspected Communists. For example, two HSI figures, Tanting Ngo and W.S. Silitonga, who were convicted on 19 October 1965, were rehabilitated by Ryacudu a month later after a personal written guarantee from Governor Oeray. ${ }^{73}$

\section{PARTINDO AND IPKI}

Although West Kalimantan Partindo initially was spared from persecutions that other branches experienced, its leaders knew the danger was imminent and the future of the party was bleak. One party official recalled that shortly after the coup, Partindo's headquarters were moved from central Pontianak to a rather obscure place beside a rented motorcycle workshop, and that its leaders were in semi-hiding. ${ }^{74}$ The dismissal of Oeray in July 1966 ended the remaining source of protection for Partindo.

Unlike Partindo in other places where the party had disbanded itself or was frozen by local authorities, West Kalimantan Partindo still officially existed. The new regime wanted to handle West Kalimantan Partindo carefully to avoid unnecessary political and social risks. By 1965 Partindo was undoubtedly the largest force in West Kalimantan politics, at least in terms of membership. Its leaders were highly charismatic for many of its large Dayak followers. Rather than disbanding the party, a move that could create unrest, the regime merged it into a trusted politi-

$7^{2}$ At least in 1963, the local newspaper Bebas did not make any references to Communist unilateral action like those in Java and elsewhere. Related local military publications also did not indicate such action took place. At the national level, Ricklefs (2001:331-2) reported that the unilateral action mainly occurred in Java, Bali, and North Sumatra. The only written indication of the Communist unilateral action in the province was from a short memoir by Lim Bak Meng who mentioned that in 1963 the Catholic Party was busy dealing with the action from BTI and SOBSI, two affiliates of PKI (Lim Bak Meng, 'Riwayat perjuangan', 1978, in: Private collection, Pontianak).

73 Interview with Ttg; Ryacudu, 'Surat keputusan tentang rehabilitasi 2 orang anggauta bekas HIS', 1965, in: Collection of St. Ngo Lahay, Pontianak. Davidson (2008:57) also notes existing amicable relations between Ryacudu and Sofyan, the head of West Kalimantan PKI.

74 Interview with Mgk. 
cal party, IPKI. Facilitated by the military, ${ }^{75}$ West Kalimantan Partindo leaders convened an extra-ordinary party conference on 26 September 1966 to declare the merger. West Kalimantan IPKI officially accepted the merger on 28 September 1966, followed by military approval on 6 October 1966. ${ }^{76}$ The regional Military Commander, Ryacudu, approved the merger on 16 October 1966 and instructed that this 'Partindo solution' be disseminated as widely as possible. ${ }^{77}$

\begin{tabular}{|c|l|c|c|c|c|c|c|c|}
\hline \multicolumn{2}{|c|}{ Province/District } & IPKI* & PK & PNI & NU & PKI & MURBA & PSII \\
\hline West Kalimantan & 29.9 & 22.9 & 22.1 & 21.4 & 2.5 & 0.9 & 0.3 \\
\hline \multirow{3}{*}{} & Pontianak City & 15.8 & 12.6 & 5.9 & 28.8 & 31.9 & 3.8 & 1.1 \\
\cline { 2 - 9 } & Pontianak & 28.7 & 22.3 & 7.8 & 37.4 & 1.4 & 2.2 & 0.1 \\
\cline { 2 - 9 } & Sambas & 29.5 & 2.4 & 28 & 33.2 & 5 & 1.3 & 0.7 \\
\cline { 2 - 9 } & Sanggau & 39.2 & 26.1 & 32.2 & 1.9 & 0.3 & 0.1 & 0.3 \\
\cline { 2 - 9 } & Sintang & 42.8 & 26.4 & 20.5 & 10.1 & 0.2 & 0 & 0 \\
\cline { 2 - 9 } & Kapuas Hulu & 26.3 & 32.9 & 28.8 & 11.9 & 0 & 0 & 0 \\
\cline { 2 - 9 } & Ketapang & 15.8 & 35.6 & 23.8 & 23.9 & 0.3 & 0 & 0.6 \\
\hline
\end{tabular}

Table 5.3 Estimation of strength of political parties in West Kalimantan (percentage in 1960)

*In 1960, IPKI was, in effect, Partindo.

Source: Recalculated from 'Buku petunjuk teritorial daerah Kalimantan Barat', 1972, p. 76, in: Library of

West Kalimantan Governor's Office, Pontianak.

\begin{abstract}
75 The role of the military in the merger was quite evident, as it wanted to solve the problem. In his merger speech, Ngo Lahay, the chairman of Partindo, also indicated the important roles of Regional Military Commander Ryacudu, and his aide, Lieutenant Colonel Siswojo Atmodihardjo (appointed as mayor of Pontianak City in 1967), in the merger process. He also mentioned other important figures in Jakarta who were involved in the process, namely General Nasution, Professor Umar Senoadji, and Brigadier General Sukendro (Stephanus Ngo Lahay, 'Pidato pernjataan Partindo Kalbar dileburkan didalam IPKI', 1966, in: Collection of St. Ngo Lahay, Pontianak). One participant at the conference on 26 September 1966 also recalled the role of the military officials in preparing and setting up the conference (interview with $\mathrm{Kdr}$ ).

$7^{6}$ Ryacudu, 'Surat pengesjahan peleburan Partindo (Partai Indonesia) daerah Kalimantan Barat kedalam partai IP-KI wilajah Kalimantan Barat', 1966, 'Pernjataan menerima peleburan dari Partindo', 1966, St. Ngo Lahay, 'Pernjataan peleburan partai Indonesia (Partindo) Kalimantan Barat kedalam Partai Ikatan Pendukung Kemerdekaan Indonesia wilajah Kalimantan Barat', 1966, in: Collection of St. Ngo Lahay, Pontianak.

77 Ryacudu, 'Surat pengesjahan peleburan Partindo (Partai Indonesia) daerah Kalimantan Barat kedalam partai IP-KI wilajah Kalimantan Barat', 1966, in: Collection of St. Ngo Lahay, Pontianak.
\end{abstract}


There were several reasons behind the military preference for IPKI over other political parties. IPKI was only a small political party supported by military retirees and veterans, and most importantly a strong supporter of the New Order. The regime's trust in IPKI could be seen in a similar case in North Sumatra, where the regional military commander, Sarwo Edhie Wibowo, preferred that ex-members of PNI join IPKI (Sjamsuddin 1984b:180-6). The merger of Partindo into IPKI would give the government access to control over leaders and the large number of followers of the former Partindo. For Partindo, merging into the military-backed IPKI was the safest option because of the growing power of the military within the new regime. Association with the military could also neutralize the party's past links with the left. ${ }^{78}$ Also, IPKI's nationalist platform was more acceptable for predominantly non-Muslim Dayak members of Partindo.

Merging with other parties was less desirable for Partindo. The Catholic Party was not a viable option because of the conflict between the elite of the two parties, as mentioned previously. Joining Islamic parties was also not an option because of its predominantly non-Muslim Dayak members. Joining another nationalist party, PNI, was not desirable either for Partindo or the regime. Partindo would not want to merge with the Soekarnoist PNI, which had become one of the main enemies of the new regime. In Sumatra and many provinces in Java, the military had urged the dissolution of the PNI (Sjamsuddin 1984b:180-6). The regime also did not encourage merger with PNI, as it did not want to see a stronger PNI. It was not possible to merge with Sekber Golkar (hereafter Golkar), ${ }^{79}$ which had not yet emerged as a political force and was not yet recognized as the political vehicle for the new regime.

Unfortunately, not long after the merger, problems began to emerge for the new party in July and August 1967. The national IPKI leader,

78 Following the merger, Partindo quickly forged a new alignment with the New Order and shed all remaining ties with its leftist past. A letter from Sanggau IPKI dated 3 October 1966 showed that Partindo's affiliates had changed their names to include the term 'Pancasila'. For example: Gerakan Pemuda Indonesia became Gerakan Pemuda Pancasila; Gerakan Tani Marhaen became Gerakan Tani Pancasila; Gerakan Serikat Buruh Indonesia became Kesatuan Buruh Pancasila, Wanita Indonesia became Gerakan Wanita Pancasila ('Pengumuman peleburan Partindo Kalimantan Barat beserta semua organisasi massanya kedalam Partai Ikatan Pendukung Kemerdekaan Indonesia (IPKI)', 1966, in: Collection of St. Ngo Lahay, Pontianak). Because of this merger, West Kalimantan IPKI inherited a few 'extra' affiliates which did not exist in other IPKI branches.

79 Sekber Golkar was established in October 1964 by the military in order to coordinate army-civilian cooperative bodies to counter growing political influence of PKI (Ricklefs 2001:334). 
Brigadier Sukendro, was detained in a wave of arrests to uproot proSoekarno elements within the military. ${ }^{80}$ The role of General Nasution, one of the founders of the New Order who was considered the founder and benefactor of IPKI, also declined after 1968 because of his growing opposition to the newly elected president. ${ }^{81}$ Towards the end of the 1960s, Golkar had emerged as the sole political vehicle of the regime; consequently, other political parties had lost influence. This overall trend at the national level weakened IPKI considerably. The condition of West Kalimantan IPKI was even worse; internal friction between the original members (the Malays) and new members (the Dayaks), had weakened the party considerably.

\section{MANOEUVRES TO SUPPORT GOLKAR}

By 1969, Soeharto had strengthened his position. He had not only successfully secured support from the central and regional bureaucracies, but had also installed his loyalists in most key military positions by eliminating or sidelining dissident officers. ${ }^{82}$ On the economic front he had stabilized the economy and had embarked on the first Five Year Development Plan (Repelita). Concerned about legitimizing his regime, Soeharto decided to call the election, which had been postponed since 1968.

At the beginning of his regime, Soeharto did not plan to use Golkar as the main political machinery to contest the election. As mentioned above the regime had encouraged certain political parties in the regions to merge with IPKI. The regime's cultivation of relations with political parties such as PNI led many to believe that it would be cooperating with those parties in the post-election government (Crouch 1978:265; Van der Kroef 1971). Golkar leaders themselves only aspired to be one of the big three in the election (Crouch 1978:264-5). Only as the 1971 election

\footnotetext{
8o Van der Kroef 1971:98. In 1965, Sukendro was Army Intelligence Chief and an ally of General Yani who was killed in the 1965 coup attempt. He then became a minister in the Second Revised Dwikora Cabinet (March-July 1966). Nasution speculated that Sukendro was arrested for trying to help Soekarno out (Nasution 1988:8-9).

${ }_{81}$ General Nasution was a target in the 1965 coup attempt, but escaped. He was appointed chairman of MPRS from 1966 and had chaired sessions of the Provisional MPR that revoked the presidential mandate of Soekarno in 1967. Nasution's political influence and independent views started to distance him from the new regime. He was eased out from the New Order power circle after the Provisional MPR sessions in March 1968, and finally retired from the army in 1972 (Nasution 1998:Chapter VIII).

82 Crouch 1978:221-44; Ricklefs 2001:297-8; Van der Kroef 1971; Ward 1974:8-9.
} 
approached did the regime decide to use Golkar as its sole vehicle to win the election. This had the effect of increasing the regime's hostility toward other political parties.

To weaken other political parties, the government used Opsus to instigate internal party struggles. ${ }^{83}$ The main objective of this intervention was to remove the recalcitrant or pro-Old Order leaders before the election and establish control over the parties under new leaderships. All the major political parties, NU excepted, as well as other functional and professional groups, such as associations of journalists (PWI), lawyers (Persahi), and medical doctors (IDI), were subjected to internal purges. With the support of the regime, the pro-New Order leaders of those organizations won the contests and subsequently collaborated consciously with the regime (Crouch 1978:245-72; Nishihara 1972:21-2; Ward 1974:17-9).

Policies and regulations were also engineered to help Golkar win. Permen 12/1969, promulgated in December 1969, required members of the functional group in national, provincial and district legislatures to sever their affiliations with political parties. Since this group occupied more than half of the parliamentary seats, their switch to Golkar was a windfall for Golkar. Political parties resented this new requirement since many members of the functional group in the Parliament had links with them (Ward 1974:11). For example, 76 of the 242 members of the functional group in DPR-GR were affiliated with political parties (Crouch 1978:247-8). Similar severings of ties also happened in West Kalimantan, where many of the legislators became members of Golkar. ${ }^{84}$

83 Sebastian 2006:456. Opsus was set up by Soeharto during the Irian Barat campaign (1963-1966) to compile political intelligence and at times was used by the President to conduct sensitive foreign diplomatic assignments. Ali Murtopo headed the unit for many years. Opsus was linked to the implementation of the Act of Free Choice in 1969, through which Irian Barat became a province of Indonesia. It was also involved in negotiations with Portugal regarding East Timor in the mid-1970s (Kingsbury 2003:1289; Sebastian 2006:45-6).

84 'Laporan kerdja tahun 1963', 1964, pp. 8-9, 'Laporan umum Gubernur Kepala Daerah Propinsi Kalimantan Barat kepada menteri dalam negeri', 1970, pp. 14-5, 'Buku petunjuk teritorial daerah Kalimantan Barat', 1972, p. 81, in: Library of West Kalimantan Governor's Office, Pontianak. F.X. Jos Diit Sinsang, who was a member of Partindo and then IPKI, was appointed by Golkar as a Member of Parliament representing intellectuals from Golkar. He wrote a letter of resignation to Golkar in March 1970 explaining that according to regulation Permen 12/1969 he could not be a member of a political party (IPKI) while holding a seat representing a functional group (F.X. Jos Diit Sinsang, 'Surat pengunduran diri dari keanggotaan DPRD-GR dari Gol. Kar. Tjendekiawan Kabupaten Sambas', 1970, in: Collection F.X. Jos Diit Sinsang, Singkawang). Diit Sinsang was arrested in early 1971. 
Another policy, PP 6/1970, aimed at preventing civil servants from supporting political parties was promulgated in February 1970.85 This policy cut off ties between the political parties on the one side and civil servants and army members on the other. This created a serious problem for parties, particularly for PNI, which received strong support from the civil service. Civil servants in West Kalimantan, as in many other places, were also required to give their loyalty only to Golkar (monoloyalitas). For example, all sub-district heads in Sanggau district were asked to sign a statement called Pernyataan Bersama Camat Sekabupaten Sanggau (Declaration of Sub-District Heads in Sanggau District). In the statement dated 7 April 1970, they declared the severing of their ties with political parties. ${ }^{86}$ In effect, the local bureaucracy had no choice but to ensure Golkar won the election or face disciplinary actions from the regime. ${ }^{87}$

\section{GOLKAR, IPKI AND THE ELECTION OF 1971}

Internal friction within West Kalimantan IPKI between the original Malay members and new former Partindo Dayak members started to appear soon after the merger. The original Malay members of the party were not satisfied with the merger, as they were not much involved in the process. The merger decision was made by the regime and party headquarters in Jakarta and organized by them. Malay leaders in the party were also dissatisfied with their loss of their dominance in the party leadership because of the growing influences of Dayak leaders within the party. In terms of the ethnic composition before the merger, West Kalimantan IPKI was basically a Malay party, but after the merger, Dayak figures penetrated every part of its leadership structure. Party organization structure on 28 October 1966 showed that at least 40 per cent of party officials were Dayaks (18 out of 43), and Oevaang Oeray was made the Advisor to the party. Malay dissatisfaction was exacerbated by the rather high expectations of the new Dayak members, whose party

\footnotetext{
$8_{5}$ The law only included military and the police, employees in the defence ministry, and other civil servants as stipulated by the President, but in practice almost all civil servants were bound by this regulation (Ward 1974:12).

86 'Pernyataan bersama tjamat seKabupaten Sanggau', 1970, in: Private collection, Sanggau.

87 During the New Order regime it was quite common that officials who failed to win for Golkar in the election be demoted. Civil servants who were known to support other political parties were usually required to resign from their government jobs.
} 
was once much more influential than IPKI. Internal friction between the Malays and Dayaks was inevitable.

In 1968, Tan Husni Abdullah, the Malay chairman of IPKI, decided to expel all ex-Partindo members from the party. He reasoned that some of them were involved in the banned organizations, such as Baperki, HSI, and PKI. However, this decision was annulled by headquarters on the basis that before the merger all ex-Partindo members in the party at that time had obtained security clearances after thorough military screenings. IPKI headquarters then took over the party leadership of the province to prevent further disintegration (IPKI 1971). ${ }^{88}$ On 27 February 1970, the headquarters gave a mandate to Ibrahim Saleh, a Malay founder of West Kalimantan IPKI, to form a new party leadership. The final party leadership, legalized on 16 June 1970, included only 28 per cent Dayaks (6 out of 21). Most former senior Partindo members were excluded from the new structure, ${ }^{89}$ very likely in order to reinstate Malay supremacy in the party and to prevent the development of a stronger Dayak influence in the party leadership.

As the 1970 election approached, calls for the arrest of ex-Partindo members within IPKI emerged. In the beginning, the new Regional Military Commander Soemadi (note that the governor also had the same name), who was installed just a few months earlier, issued a statement to back his predecessor's stand on the 'innocence' of West Kalimantan Partindo. ${ }^{90}$ The statement on 7 October 1970 ruled that Partindo was not an illegal party, and ex-Partindo members in IPKI who had ties with Baperki were allowed to conduct political activities as long as they were not involved in the 1965 coup nor had become underground members of PKI.91 Nevertheless, mounting pressure forced Ngo Lahay, the former chairman of Partindo and at that time a member of provincial

88 Achmad Sukarmadidjaja and H. Djilis Tahir, 'Partai IP-KI Kalbar', 1971, in: Collection of St. Ngo Lahay, Pontianak.

${ }_{9}$ Achmad Sukarmadidjaja and H. Djilis Tahir, 'Surat keputusan susunan dewan pimpinan wilajah partai IPKI Kalimantan Barat', 1970, in: Collection of St. Ngo Lahay, Pontianak.

9o The military commander before Soemadi was Antonius Johannes Witono Sarsono (July 1967-April 1969). Prior to Witono was Ryacudu (September 1963-July 1967). For the complete list of the military commanders from the 1950s to 1980s, see Army territorial commanders 1983:117.

${ }_{91}$ Soemadi, 'Press release tentang status Partindo', 1970, in: Collection of St. Ngo Lahay, Pontianak. PKI allowed its members to become members of other parties. 
legislature representing IPKI, to resign on 11 October $1970 .{ }^{92}$ On 15 January 1971, after almost four-and-a-half years since the 1965 coup, the military decided to arrest some core ex-Partindo/Baperki members: Ngo Lahay, H.G. Mihing and Tanting Ngo in Pontianak; M. Idris and Diit Sinsang in Sambas area; and Phillips Neng in Sanggau. All were barred from public gatherings and were not allowed to participate in the 1971 election. Another Partindo figure, E.D. Tundang, who headed a government office, was charged with corruption and arrested on 2 March $1971 .^{93}$

The remaining but the most important target, was former Governor Oeray, who was still active working at the governor's office at the time of those arrests. With the rank of resident, he was one of the highest active civil servants at the provincial level, who was not on Golkar's side. ${ }^{94} \mathrm{He}$ maintained his political association with IPKI, and was listed as the party's main candidate for the election. Understanding Oeray's influence, the military commander, who had the final say on the list of legislature candidacies, keep Oeray's candidacy, but demoted his position to number 20 on the list, an unelectable position. ${ }^{95}$ Oeray, who was at the time the head of the Regional Screening Committee, was not satisfied with the change. Facing Oeray's defiant attitude, the military commander planned to arrest him. However, Governor Soemadi was not keen on having Oeray arrested, fearing that it could create unnecessary political risks that could disturb the election which was due in four months' time and undermine his authority. He asked the minister of internal affairs to promote Oeray and used the promotion as a pretext to transfer him to Jakarta. ${ }^{96}$ The minister agreed and issued the promotion on 28 February 1971. On 9 March 1971, approximately a week after the promotion, the letter for his transfer was out. Knowing of the scheme to uproot him

\footnotetext{
92 Soenandar Prijosoedarmo, 'Menyetujui pemberhentian sdr. Stephanus Ngo Lahay', 1971, in: Collection of St. Ngo Lahay, Pontianak. By this time, Ngo Lahay although still a member of IPKI, was removed from the leadership structure in June 1970. The only senior Dayak leaders in the structure were E.D. Tundang, A. Sawa, and Asam Djarak. Tundang would soon be arrested, while Sawa and Djarak would be joining Golkar.

93 A higher court in Jakarta found he was not guilty and ordered his release on 24 September 1973 (Akcaya, 18-4-1977).

94 Another party figure in the bureaucracy, Dr Soedarso from PNI, was forced to retire shortly before the election.

95 'Laporan Gubernur Kepala Daerah/ketua Panitia Pemilihan Daerah Tingkat I Kalimantan Barat', 1971, in: Library of West Kalimantan Governor's Office, Pontianak. The original position of Oeray in the list was not disclosed, but probably was within the top five.

$9^{6} \quad$ Interview with Smd.
} 
from his power base in Pontianak, Oeray initially refused to comply with the transfer. ${ }^{97}$ Not until 20 March 1971 did he finally decide to leave; it was clear that arrest by the military was imminent if he refused to board the plane to Jakarta. ${ }^{98}$

The arrests of the former Partindo members in January 1971 and removal of Oeray were the regime's last resort after persuasion to make them affiliate with Golkar failed. ${ }^{99}$ Their arrests had been delayed several times since the first arrest warrant was issued in December 1969 and then again on 2 November 1970. ${ }^{100}$ This delay gave time for the military and Golkar to persuade the ex-Partindo members of IPKI to switch sides. An internal IPKI document explains that some time in 1969, the West Kalimantan military authority sent Lieutenant-Colonel Nurdin Djain to Jakarta to persuade the leaders of the national IPKI to allow all ex-Partindo members of West Kalimantan IPKI to be transferred to Golkar. This request was rejected by IPKI headquarters. The document also disclosed Golkar's approaches to recruitment of members of West Kalimantan IPKI, particularly those from lower echelons. ${ }^{101}$ Various personal interviews also confirm that the military threatened ex-Partindo members with imprisonment if they refused to join Golkar. Prior to the election a document was circulated which contained the names of more than ten leaders of the former Partindo in Pontianak who were to be arrested - undoubtedly putting more pressure on the Dayak leaders to switch to Golkar. ${ }^{102}$

The military and the regime efforts finally paid off within a month of Oeray's departure to Jakarta. On 17 April 1971, five senior Dayak leaders, A. Djelani, P. Anjiem, I. Kaping, A. Sawa, and J.A.M. Linggie, together with other Dayak figures, publicly announced that they were joining Golkar. Two of them, A. Sawa and Asam Djarak, were IPKI

97 Interviews with Bln and Syk.

$9^{8}$ For the dates, see Varia 1971/6:25. The central government once contemplated removing Oeray from West Kalimantan after the 1967 conflict (interview with Mgn; Doera 2003:122).

99 Oeray's refusal to switch to Golkar had influenced many of his followers not to join Golkar.

1 To These were based on private communications from Diit Sinsang to Oevaang Oeray (F.X. Jos Diit Sinsang, 'Persoalan keanggotaan ex Baperki dari rekan2 ex Partindo Kab. Sambas', 1970, in: Collection F.X. Jos Diit Sinsang, Singkawang), as well as official documents from IPKI (Achmad Sukarmadidjaja and H. Djilis Tahir, 'Partai IP-KI Kalbar', 1971, in: Collection of St. Ngo Lahay, Pontianak). According to Sinsang, the instructions were based on Kogam Instruction No. 9/1965 that all officials of Baperki be classified in 'B Group', and if they were civil servants they should be dishonourably discharged.

101 Achmad Sukarmadidjaja and H. Djilis Tahir, 'Partai IP-KI Kalbar', 1971, in: Collection of St. Ngo Lahay, Pontianak.

${ }_{102}$ Interview with Lnj. 
officials in the new structure formed in June 1970. The others were probably still members or sympathizers of IPKI before they decided to join Golkar. In the statement, they advised other Dayaks to follow suit and give assistance to local authorities, especially the military commander, to make a success of the election and the development program of the New Order. A special taskforce was formed to inform local Dayaks about the change in political alignment of their leaders. ${ }^{103}$ On 19 May 1971, Nurdin Djain, this time as general chairman of West Kalimantan Golkar, instructed these Dayak figures to campaign for Golkar. On 24 May 1971, these Dayak leaders announced that thousands of Dayaks had chosen to join Golkar. In the same document they also denied rumours that they had been coerced into joining Golkar by intimidation. ${ }^{104}$

Pressure on IPKI and other political parties increased as the election approached. ${ }^{105}$ Golkar and the military rightly had concerns about IPKI, because it had become one of the largest political parties in West Kalimantan following its absorption of Partindo. Some district Regional Governing Councils (Muspida) had urged IPKI branches to disband themselves. ${ }^{106}$ The head of Ketapang IPKI at that time, for example, decided to dissolve the party upon receiving advice from the local military commander. ${ }^{107}$ Six of the party's candidates, most possibly of exPartindo background, were disqualified by the local military commander. That number was the highest among the political parties in the province (Nishihara 1972:59).

During the election campaign, political parties in many areas were intimidated and unable to campaign properly. The head of Pontianak district IPKI, who was later to become a member of Golkar, recollected being detained and intimidated by the military so that he joined Golkar. ${ }^{108}$ Similar intimidation was felt in Sintang ${ }^{109}$ and very likely also in other interior districts. In contrast, Dayak leaders campaigned freely

\footnotetext{
103 'Pernyataan bergabung dengan Sekber Golkar', 1971, in: Private collection, Sanggau.

${ }_{104}$ 'Pendjelasan tentang pernjataan bergabung dengan Sekber Golkar', 1971, in: Private collection, Sanggau.

${ }_{105}$ Political pressure and intimidation toward political parties were also common in many parts in Indonesia as the regime tried hard to ensure that Golkar won. The phenomenon of self-disbanding of political parties as the result of political pressure was quite common at this time.

106 Achmad Sukarmadidjaja and H. Djilis Tahir, 'Partai IP-KI Kalbar', 1971, in: Collection of St. Ngo

Lahay, Pontianak. Muspida is made up of the heads of the military, police and civil administration.

107 Interview with Smj.

108 Interview with Shd.

109 Interview with Mjg.
} 
for Golkar. In the end, West Kalimantan IPKI managed to get only two seats in the provincial DPRD, the fifth rank after Golkar, NU, Parmusi and PK. ${ }^{110}$ Both seats were given to Malays-- the first and third candidates. The second candidate on the list, Herman Imang Ngo - a Dayak, who should have been elected-- was bypassed. ${ }^{11}$ No doubt Dayak votes had contributed significantly to the winning of those two IPKI seats. As an illustration, the sub-district head of Meliau during the election explained that the party won 100 per cent of the votes in some remote Dayak villages under his control. He found out later that the Dayaks in these areas were not aware of the recent changes in the political affiliation of their leaders to Golkar. ${ }^{112}$

\section{DAYAK POLITICS AND CONFLICT IN 1967}

Communists and their sympathizers had become the target of the purging operation throughout Indonesia after October 1965. In some regions in Java, Bali, and Sumatra, the anti-Communist mobs supported by the army rounded up and killed suspects Communists en masse. In Java and Bali, mass killing intensified as soon as the RPKAD, a crack unit within the army, came to the regions. The military and the police were also reported to allow or even encourage the murders to take place (Cribb 1990).

Conflict of a different nature also occurred in West Kalimantan some time after the mass killing elsewhere had stopped. Between September and November 1967, tens of thousands of Chinese who lived in the northern part of the province were driven out from their homes by Dayaks. Many of those Chinese who refused to move or who retreated too late were killed. The official record was 249 deaths and almost 60,000 refugees at the end of the conflict. ${ }^{113}$ There has been a strong belief among scholars that the Dayaks were not capable of inflicting such

11 IPKI obtained no seat at the national level and ranked only ninth out of ten parties in West Kalimantan.

111 According to one ex-Partindo member, at this time, ex-Partindo leaders were only guests in IPKI. Important decisions were in the hands of Tan Husni and Ibrahim Saleh, both Malays (interview with Shd).

112 Interview with Omr.

113 Davidson 2008:67; 'Pengungsian orang2 Tjina sebagai akibat gerakan2 orang Daya dalam daerah Kabupaten Pontianak dan Kabupaten Sambas', 1967, Library of West Kalimantan Governor's Office, Pontianak. 
cruelty on the Chinese without a third party being involved - such as, in this case, the army (Davidson 2002, 2008; FEER 1968). Members of the Dayak political elites who had just lost their positions were also suspected of waging war on the Chinese to show their allegiance to the new regime and at the same time to regain its trust. This section will re-investigate these claims by examining some new evidence.

\section{CHRONOLOGY OF THE CONFLICTS}

The spark of conflict had begun at least a week earlier than the commonly cited 14 October 1967 in Uduk Village. ${ }^{114}$ A confidential report prepared by the governor's office ${ }^{115}$ listed earlier Dayak attacks between 5 and 7 October, when they burned and looted Chinese houses in Tepo village, Air Besar (Landak), adjacent to Sanggau Ledo (Bengkayang). These acts were followed by similar incidents in the Bengkayang subdistrict from 13 October, which prompted the worried Chinese to seek refuge in Bengkayang City. In one incident, the Dayaks killed several Chinese in Sansak village in retaliation for the rebel attack on a nearby Uduk village. The rebels, as will be discussed below, were mostly Chinese. By 18 October Bengkayang City already sheltered about one thousand refugees. On 19 October Dayaks in Samalantan (Bengkayang) started to distribute 'red bowls', a Dayak call for mass mobilization for war. After the distribution of the red bowl, Dayak mobilization against the Chinese intensified, and the conflict had evolved into a traditional war in which all adult Dayak men were obliged to join the call to fight the enemy (in this case, the Chinese).

Sporadic killings had occurred from mid-October although the more deadly killings did not occur until after 28 October 1967. The three most deadly attacks happened during the first and second weeks of November in Senakin, Darit and Sebadu, all in Landak district, and claimed a total of 210 lives. ${ }^{116}$ Only after these attacks did the military commander, on 17 November, order the Dayaks to stop the demonstrations and ordered

\footnotetext{
${ }_{114}$ For such an oversight, see FEER 21/27-1-1968, Davidson 2008:66-7; Rachman et al. 1970:271.

115 'Pengungsian orang2 Tjina sebagai akibat gerakan2 orang Daya dalam daerah Kabupaten Pontianak dan Kabupaten Sambas', 1967, Library of West Kalimantan Governor's Office, Pontianak.

116 'Pengungsian orang2 Tjina sebagai akibat gerakan2 orang Daya dalam daerah Kabupaten Pontianak dan Kabupaten Sambas', 1967, Library of West Kalimantan Governor's Office, Pontianak; Davidson 2002:156.
} 
the army to shoot on the spot those who refused to comply. ${ }^{117}$ The demonstrations dissipated after this injunction although a government report still mentioned occasional clashes up to the end of November 1967. ${ }^{118}$

\section{CONDITIONS PRIOR TO THE CONFLICTS}

After 1963, West Kalimantan had become a frontier for the Indonesian campaign against the formation of the Malaysian Federation by the British government. ${ }^{119}$ Indonesia sent its military forces and volunteers to Sumatra and Kalimantan, which shared a border with Malaysia. In West Kalimantan, it sheltered and trained Sarawakian guerrillas so that they could be sent back into British Borneo to disrupt the formation process (Rachman et al. 1970:232-5). Between October and November 1965 there were 2,313 volunteers in the province (Davidson 2008:55).

Activities of the guerrillas were relatively undisturbed during the political transition in Indonesia between 1965 and early 1967. In fact, after the abortive coup, the government continued its anti-Malaysia campaign and therefore would not dispense with the rebels (Rachman et al. 1970:240). The Indonesian military still conducted guerrillas training as late as August 1966 (Davidson 2002:133). Anti-Communist drives in the province initially were not directed at the Communist guerrillas who were fighting the establishment of the Federation of Malaya, but against members of PKI and its sympathizers. Because of this condition, the activities of Communist rebels in Indonesian Kalimantan seemed to regain their vigour whereas Communist activities elsewhere had almost stopped (Davidson 2008:66; Van der Kroef 1968a:251-2). One source, for example, mentions a number of incidents related to the increased PKI activities in coastal towns between August and November 1967 (Davidson 2008:66).

Initially the Indonesian government did not perceive rebels as a threat because their political aim was to sabotage the formation of the Federation of Malaysia by overthrowing the Sarawakian government.

117 A.J. Witono, 'Maklumat', 17-11-1967, in: Collection of S. Jacobus E. Frans Layang, Pontianak; Pembangunan, 21-11-1967.

118 'Pengungsian orang2 Tjina sebagai akibat gerakan2 orang Daya dalam daerah Kabupaten Pontianak dan Kabupaten Sambas', 1967, Library of West Kalimantan Governor's Office, Pontianak.

119 Soekarno saw the Federation as a puppet state and a new form of colonization, a threat to Indonesia. He believed that the decision to form the Federation was made without full consultation of the local population, particularly in Sarawak and Sabah. 
Rebels became a security risk to Indonesia only when they refused to disarm and surrender after both Indonesia and Malaysia ended the confrontation on 11 August 1966. ${ }^{120}$ In October 1966, the Indonesian army began operations to regain control over rebel strongholds, and clashes were unavoidable. ${ }^{121}$ By this time, small numbers of ex-PKI members who had evaded capture by the Indonesian government had joined the guerrillas. The rebel group was largely under the domination of Sarawakian Chinese. ${ }^{122}$ However, the operations were not adequate to uproot the guerrillas ${ }^{123}$ until the attack on a military depot in Sanggau Ledo (Bengkayang) on 16 July 1967, where the rebels killed several guards and absconded with significant amounts of arms and ammunition Then the central government stepped-up the operations $0 .{ }^{124}$ National newspapers, such as Kompas and Angkatan Bersenjata started to cover the guerrilla issue more seriously.

120 Only 99 surrendered, while 739 Chinese volunteers chose to remain at the Indonesian border to continue their operation ('Pengungsian orang2 Tjina sebagai akibat gerakan2 orang Daya dalam daerah Kabupaten Pontianak dan Kabupaten Sambas', 1967, p. 82, in: Library of West Kalimantan Governor's Office, Pontianak). A general amnesty was also offered by the Sarawak government to the Communist guerrillas between July 1966 and January 1967, but it only resulted in 41 surrenders (Van der Kroef 1968a:253).

121 For details of the operation, see Rachman et al. 1970:239-339. Some of these operations were not successful. The first cause was the withdrawal of all special combat units from West Kalimantan and their role was transferred to less experienced local army units. The local army units were inexperienced because they had not been involved directly in the military operation during the confrontation. Secondly, there was no handover of intelligence information during the transfer. Another obstacle was the small size of the army compared to the vast territory. Undoubtedly there were also Communist cadres within the army which further undermined the military actions against the rebels (interview Djg; Kompas, 9-81967; Davidson 2002; Rachman et al. 1970).

122 Soemadi, 'Press release tentang status Partindo', 1970, in: Collection of St. Ngo Lahay, Pontianak. From this time on, the rebel forces were comprised of Paraku, PGRS, Indonesian volunteers, and PKI members. The Paraku rebels were concentrated on the eastern border, while PGRS was mostly situated on the western front (Davidson 2002:133-4). This chapter will use the terms 'guerrillas' and 'rebels interchangeably.

123 The underlying reasons behind this less serious campaign, according to Davidson, partly included the regime's pre-occupation with eliminating the Communists in Java and Bali, and partly the misjudgement about the real conditions in West Kalimantan. Furthermore, it was difficult for the existing military to effectively act against the rebels whom they had earlier supported and trained (Davidson 2002:143-4). ${ }_{124}$ Van der Kroef 1968a:257; Rachman et al. 1970:260. The rebels seemed to have intelligence about the layout of the military depot; hence the successful attack. The government suspected the complicity of internal sources and the Chinese, particularly those who lived near the military depot and those who had business dealings with the military, and were therefore familiar with the depot (Rachman et al. 1970). 


\section{RISING ANTI-CHINESE SENTIMENT}

Indonesia's relations with the PRC after the coup in 1965 deteriorated rapidly as the PRC continued to praise Indonesian Communists and denigrate the incoming regime. The deteriorating relations reflected badly on the Chinese in Indonesia, many of whom held PRC citizenship. Anti-Chinese incidents were on the increase, ranging from demonstrations to demand their repatriation, nationalization of their businesses and restrictions on their business, education and social activities, to physical attacks on Chinese individuals and their property. ${ }^{125}$ The spiralling number of incidents spreading from one place to another was partly due to the lack of government action to punish the perpetrators; this inaction was perceived as government approval. Reports of antiChinese attacks by the national press were also picked up and reprinted by local newspapers, resulting in an increase of local hostility toward the Chinese.

In West Kalimantan, the Chinese were also ostracized. Several years prior, implementation of Government Regulation Number 10 (better known as PP 10) on alien Chinese business and trading activities and a series of regulations from the Regional Military Emergency Authority pertaining to Chinese schools had started to show some negative effects in the province. ${ }^{126}$ The government tended to be suspicious of and anxious about the activities of the Chinese, a large non-assimilating community in the province, and the abortive coup in 1965 offered a pretext for the new regime to deal harshly with the Chinese issue. All Chinese schools in the province were closed by the end of April 1966, mostly after being raided by military-approved youth demonstrators. ${ }^{127}$ In December 1966, leaders of Zhonghua Gonghui throughout the province were hastily summoned by the military commander to Pontianak for depor-

125 Setiono 2003:Chapter XLIX; Coppel 1983; Van der Kroef 1968b:26-36; Staf Chusus Urusan Tjina, 'Laporan tahun 1968', 1968, pp. 26-39, in: Library of West Kalimantan Governor's Office, Pontianak.

126 Interview with Nzb. Further details on these measures, see Mary F. Somers 2009:31, 34-9.

127 This closure was slightly later than those in some parts of Java and Sumatra. 
tation, which was never carried out. ${ }^{128}$ Early in 1967, the government authorities had forced nearly 8,000 Chinese to work on the SingkawangSeluas road, some 3,000 to open rice fields in Sanggau, and another 600 to build an army barracks in Semitau in Kapuas Hulu district (Davidson 2008:61). In January 1967, military authorities began the resettlement of an initial 5,000 Chinese away from the Sarawak border. The Chinese were no longer allowed to live within five miles of the border (Van der Kroef 1968a:255). On 17 February 1967, about 545 alien Chinese were gathered in Pontianak for eventual repatriation back to China, but were returned to their villages later because there was no transportation. ${ }^{129}$ In April 1967, the government announced a plan to repatriate 350,000 Chinese to PRC. ${ }^{130}$ In sum, the Chinese had become targets of the new regime, and military authorities were able to exercise authority over the Chinese.

Most West Kalimantan Chinese were believed to be sympathetic to the Communist rebels, although they were not necessarily ideologically Communists (Houliston 1963:14; Peterson 1968:17). In some areas, local Chinese support for rebels was strong. One key PKI figure who was captured in 1967 claimed that the rebels' influence in the Chinese villages was almost 100 per cent. The source maintained that more than 90 per cent of Chinese youth in those areas were Communist sympathizers, and around 20 per cent of its youth were active members of the rebel group (Rachman et al. 1970:259, 276). Ethnic and cultural similarities between

\footnotetext{
${ }_{128}$ Zhonghua Gonghui was the main organization of totok Chinese, most of whom did not have Indonesian citizenship and were oriented to mainland China (People's Republic of China, or PRC). It was formed in the province after WWII and played significant roles in solving issues related to alien Chinese in the province.

For example, the organization helped to solve civil disputes among the Chinese, helped the Chinese to complete the paperwork required by the Indonesian government, facilitated the issuance of PRC passports, and supported Chinese education in the province (interview with Nzb, http://nanyang.xmu.edu. cn/Article/ShowArticle.asp?-ArticleID=6515 accessed 30-12-2010). Setiono (2003:807) claimed that on 20 December 1966, the military commander banished all officials of Zhonghua Gonghui and hundreds of Chinese from the province. Several of my eyewitness sources mentioned that all of the leaders were later 'released' and free to go anywhere they liked, including returning to their hometown (interviews with Awi and Nsb).

129 'Briefing Pangdam XII/TPR di depan siswa Seskoal tanggal 14-12-1981 tentang operasi penumpasan gerombolan PGRS/Paraku dan operasi lanjutan di Kalimantan Barat', p. 2, in: Library of West Kalimantan Governor's Office, Pontianak. The Indonesian government hoped that the Chinese government would resend ships to take the Chinese away, but it did not. In 1960 the Chinese government had sent ships to transport more than 3600 Chinese of Pemangkat (West Kalimantan) back to China. See http://nanyang.xmu.edu.cn/Article/ShowArticle.asp?-ArticleID=6515 accessed 30-12-2010).

130 Van der Kroef 1968a:255. This number was too high because the total Chinese population in the province in 1971 was about 226,216, and only a fraction of them held Indonesian citizenship.
} 
the mostly-Chinese Sarawakian rebels and the Chinese of the province made cooperation between the two easier. ${ }^{131}$

After the rebel attack in July 1967 in Sanggau Ledo, local and national newspapers started to publish articles demonizing the Chinese in West Kalimantan as Communists (Tjinkom or Tjina Komunis) and West Kalimantan as a PRC enclave (Kantong RRT). ${ }^{132}$ One military priest remembered a rumour spread among the Dayaks that 80 per cent of West Kalimantan Chinese were Communist rebels. ${ }^{133}$ The military commander toured the region several months before the attacks to advise Dayaks not to trust the Chinese because they were in league with the Communists (Alexander 1973:4). The Chinese reclusiveness and insularity, and the fact that the majority of them were citizens (and presumed to be supporters) of the Communist PRG had helped the anti-Chinese campaigns. Continuous efforts to uproot Communists throughout the country, and campaigns to link the Chinese with the Communists, could have convinced the Dayaks that the Chinese, many of whom had lived among the Dayaks, were Communists or had been assisting the Communist rebels. As a result, in the eyes of the Dayaks and Malays, all local Chinese were sympathizers of the Communist guerrillas - if they were not secret members' (FEER 3/9-12-1967). At the end of the 1960 s, the relationships between many pro-rebel Chinese and some indifferent or pro-government Dayaks might have turned sour because of political differences. One source claimed that the Chinese merchants in some areas had become antagonistic to some Dayaks who were helping the military against the rebels (Rachman et al. 1970:276). This new national and local outlook shaped Dayak attitudes to the Chinese, who otherwise had maintained peaceful relations with the Dayaks. ${ }^{134}$ This

\footnotetext{
131 Pembangunan, 7-11-1967; Rachman et al. 1970:274. The other supporting fact was that the majority of the Chinese population in the province were resident aliens, who mostly supported the Communist PRC.

132 Consult articles published between September and November 1967 in Pembangunan (local newspaper) and Kompas (national newspaper).

133 The priest believed that the rumours were a distorted version of a fact that 80 per cent of the rebels were Malaysian Chinese (Doera 2003:130). Doera was a military priest in West Kalimantan (1967-1971) whose political views on the 1971 election had irritated his superior. This had led to his house arrest and his eventual resignation from the military priest position in March 1971 (Doera 2003).

134 A Protestant pastor asserts that while they did not always mingle they managed to coexist well (Peterson 1968). While Chinese traders perhaps had exploited the Dayak farmers (interview with Kpg), the majority of Chinese who lived near the Dayaks were farmers themselves. The fact that many older generations of Dayaks in conflict areas spoke Chinese dialects, and some similarities between cultural practices of the Chinese and Dayaks, show that both communities had meaningful interactions.
} 
growing anti-Chinese sentiment and continuing campaign to show that the Chinese were the enemies later became a pretext for Dayaks attacks on the Chinese.

\section{POLITICAL EXPLANATIONS: THE ROLE OF THE MILITARY}

Some sources believe that the killing of several Dayak traditional leaders, allegedly by rebels, was in fact, the work of the Indonesian military (FEER 27-1-1968; Davidson 2008:65). The conflict had helped the military to crush Communist rebels, and official documents claimed that with the disappearance of all Chinese from rural areas of Bengkayang and Landak districts, the link between local Chinese and rebels would be cut off and Communist cells consequently be disrupted). ${ }^{135}$ Also, the initial killing of the Dayaks may have tended to stir Dayaks up into fighting against rebels (Davidson 2008:65; Doera 2003:149). Some Dayaks had good relations with rebels and were not enthusiastic about the military campaign against guerrilla fighters (Rachman et al. 1970:273). Doera, for example, asserted that Dayaks in the border areas, who were not concerned with politics, had good relations with rebels (Doera 2003:149). In Sungkung and Kapuas Hulu, some Dayaks were not interested in fighting the rebels (Peterson 1968:10; Rachman et al. 1970:272-3, 247). Other 'proof' includes encouragement from the military for Dayaks to take action. Prior to the conflict, the military commander had toured the region to 'remind' the Dayaks that the Chinese were helping the rebels (Alexander 1973:4) and also urged them to avenge bloodshed with bloodshed (Davidson 2008:66). The military was also reported to have granted titular military rank to Dayak leaders and organized festive celebrations after a successful killing of suspected Communists to encourage the attacks. ${ }^{136}$

135 'Pengungsian orang2 Tjina sebagai akibat gerakan2 orang Daya dalam daerah Kabupaten Pontianak dan Kabupaten Sambas', 1967, 'Penumpasan terhadap gerombolan Tjina komunis di daerah Kalbar 1967', 1968, 'Buku petunjuk teritorial daerah Kalimantan Barat', 1972, 'Briefing Pangdam XII/TPR di depan siswa Seskoal tanggal 14-12-1981 tentang operasi penumpasan gerombolan PGRS/ Paraku dan operasi lanjutan di Kalimantan Barat', 1981, in: Library of West Kalimantan Governor's Office, Pontianak; Rachman et al. 1970. The governor, for example, claimed that 'because of the people's movement, the Communist network and cells were in disarray and [their communications] were cut-off completely'('Pengungsian orang2 Tjina sebagai akibat gerakan2 orang Daya dalam daerah Kabupaten Pontianak dan Kabupaten Sambas', 1967, in: Library of West Kalimantan Governor's Office, Pontianak.

${ }_{136}$ These practices cited by Davidson (2002:159) were mentioned in a source which refers to military tactics practised between 1969 and 1973 (Soemadi 1974:94-6). However, no evidence has yet come to light to show that they were adopted in 1967. 
The military did in fact encourage Dayaks to fight the rebels, but it is less evident that the anti-Chinese campaign was the result of a planned strategy. Although a secret intelligence operation cannot be ruled out, evidence is lacking of a high-level scheme. Coordination at the top levels of the military and bureaucracy was lacking to support the theory of an ethnic attack. If the was attacks were planned and executed from Jakarta, there should be evidence at least of some general briefings to the key local officials to ensure they had some understanding so that they worked in concert to achieve an objective. But the confusion among the top ranking regional officials and their different responses suggested that no such briefings had been given. A high ranking bureaucrat, Major Usman Idris, the head of Pontianak district and an active military officer, instructed all sub-district heads to return the Chinese refugees, particularly the farmers, to their homes so that they could take care of their crops (Pembangunan, 9-11-1967). As the head of Pontianak district, a district where major conflict had taken place, it was very unnatural that he was not briefed on the imminent conflict which would affect his jurisdiction. ${ }^{137}$ If he had been briefed about the conflict and the plan to expel the Chinese, he presumably would not have ordered the return of the Chinese farmers. Also, it seems that no important military personnel in the conflict areas were aware of impending Dayak attacks. A military priest, who had toured some of the areas before the conflict and had chatted with local military and civil leaders, found them unaware of the incoming violence. Before their relations turned sour in early 1970, this priest had close relations with the regional military commander, Witono, who was also a Catholic (Doera 2003:110).

The response of local military officers was also inconsistent, further suggesting a lack of coordination, another indication that the conflict was not planned. Davidson (2002) portrays the failure of the army to stop the marauding Dayak mobs as intentional so that the conflict would spread. However, the failure of the military to perform a more active role to stop the conflict spreading in some instances had other explanations. In the case of massacres in Senakin and Anjungan, eyewitnesses

137 Usman Idris was a local military officer who was appointed as the caretaker of district head position when the Dayak district head was removed in December 1966. Idris was then formally appointed bupati in 1968, then re-elected and served until 1977. He became the head of provincial DPRD in 1979 and was the longest serving bupati in the history of Pontianak District. All these appointments show government confidence in him. 
recalled that the small number of military personnel had been powerless to stop the mob (Doera 2003:118-20; Van Hulten 1992:294). The lack of resolute action could also have been due to the military reluctance to antagonize the Dayaks. The Far Eastern Economic Review (FEER) explained that the military authority feared that antagonizing the Dayaks would result in a backlash against the military (FEER 3/9-12-1967). In other circumstances, the military did intervene to prevent further mob violence and to restrain the movements of the marauding Dayaks. One eyewitness gives an example of military officers who intercepted Dayak mobs and ordered them not to proceed with their plan to attack the Chinese (Peterson 1968:19). In Anjungan, mobs themselves acknowledged that the military presence had prevented wholesale looting and bloodshed (Peterson 1968:28).

The military certainly wanted to see the end of Communist activities in the province, and welcomed Dayak moves against the Chinese who lived in the interior who were known to sympathise with Communist rebels. A member of Laskar Pangsuma close to the military confirmed that local military personnel in Bengkayang region had encouraged the Dayaks to force the Chinese out of region during the early days of the conflicts. ${ }^{138}$ However, the lack of coordination and confusion among top government officials and military suggests that the conflict was not as planned as some scholars were first led to believe. The conflict involved a substantial element of spontaneous and traditional warfare.

\section{ROLE OF THE REBELS}

The argument that the military had provoked Dayaks to attack Chinese who were seen as supporters of the rebels seems to have also assumed that Dayaks had no grievances against the rebels and would therefore not attack unless provoked by outside intervention. In some areas, such as Sungkung and Kapuas Hulu, the rebels were indeed reported to be friendly and helpful to the local Dayaks in order to secure cooperation and support from them (Rachman et al. 1970). However, the rebels' relations with the local Dayaks were not always amicable; some rebels were had made threats to local Dayaks who did not cooperate with them. ${ }^{139}$

${ }_{13} 8$ S. Jacobus E. Frans Layang, 'Terjadinya PGRS dan Paraku', 22-4-1969', pp. 1, 3, in: Collection of S. Jacobus E. Frans Layang, Pontianak.

139 'Tanggapan dan seruan pemuka-pemuka masjarakat Daya Kalimantan Barat di Pontianak', 31-101967, in: Private collection, Sanggau; Peterson 1968:10. 
Newspapers reported that rebels had victimized Dayaks who lived on both sides of the border for not cooperating with them (Van der Kroef 1968a:250). The Uduk incident, which was often cited as the trigger of the violence, was a rebel attack on Dayak villagers who had refused to supply food to rebels (Pembangunan, 9-11-1967). Some rebel activities were reported to affect negatively the daily activities of the Dayaks. ${ }^{140}$

Several weeks before the pogrom in mid-October 1967, rebels had killed Dayaks on some occasions, which then triggered the wider attacks. On 3 September, the Communist rebels kidnapped and killed nine Dayaks in Tamu village (Bengkayang). ${ }^{141}$ The rebels also killed a Dayak adat leader, Temenggung Garanese, around that time (Merdeka, 21-9-1967, Davidson 2008:65-6; Rachman et al. 1970:274). Davidson (2002:149-50) suspects that those killings could have been the work of the military, and discounts the fact that the rebels also had reasons for the killings (as argued above). In an investigation two months immediately after the incident, a vocal military priest close to the Dayaks and the military commander, concluded that the victims were kidnapped to carry rebel supplies, and then were killed so they could not disclose the location of the rebels' hideout (Doera 2003:130). ${ }^{142}$

Rebel threats against the Dayaks may be seen as efforts to force the latter to cooperate. However, Dayak assistance was not indispensable because the rebels could easily get all the help needed from the Chinese, who were highly sympathetic to rebels and who were still living in a large numbers in rebel strongholds in interior areas in the Bengkayang and

\footnotetext{
${ }_{14}$ 'Tanggapan dan seruan pemuka-pemuka masjarakat Daya Kalimantan Barat di Pontianak', 31-101967, in: Private collection, Sanggau; Pembangunan, 7-11-1967; Rachman et al. 1970:274.

${ }_{141}$ The correct location of places is important when assumptions are links to specific geographical location. I have seen sources which confused Tamu with Taum, a totally different village. Tamu (or Temu) is a village in southern part of Bengkayang sub-district located near the border with Landak, while Taum village is located in Sanggau Ledo in the northern part of Bengkayang sub-district.

${ }^{142}$ Although the priest's relations with the military worsened in 1970, he maintains his finding in his memoir published years later. This was in line with the story from the military source that the Dayaks were kidnapped by the rebels (Rachman et al. 1970). However, the truth will remain a mystery unless hard evidence is found, or those who were directly involved in the kidnapping, either the army or the rebel, speak out.
} 
Landak districts. ${ }^{143}$ The rebels' high level of confidence was a result of their successful attacks and the lack of effective counterattacks from the Indonesian army (Peterson 1968:10; Rachman et al. 1970:274), and they may have become unsympathetic when dealing with locals. ${ }^{144}$ One high profile attack was the successful raid on the military depot in Sanggau Ledo in July 1967, mentioned above.

\section{ROLE OF DAYAK ELITES AND LASKAR PANGSUMA}

The last issue to be addressed is the role of Dayak elites, particularly those in the Laskar Pangsuma Militia (Laskar Pangsuma), in the conflicts. A document produced by a member of Laskar Pangsuma mentions that Oevaang Oeray and Herman Imang Ngo declared war against the Communists (that is Chinese in the hinterland) on two separate occasions, on 21 and 25 September. The same document also shows the involvement of other Dayaks associated with Partindo and Laskar Pangsuma in the later conflicts. ${ }^{145}$

Laskar Pangsuma was formed on 3 November 1967, following a meeting of Dayak elites in Pontianak with Dayak leaders from Sambas and Pontianak districts at the end of October 1967. ${ }^{146}$ According to a member of the Sambas Dayak delegation, they were flown to Pontianak by a military helicopter to respond to some accusations against the Dayaks, such as that Dayaks in Bengkayang and surrounding areas had joined the rebels to kill the Chinese. ${ }^{147}$ The delegation first saw Military

${ }^{143}$ Relations of many Chinese and Dayaks were worse in Sarawak. The core of the rebels was among the Sarawakian Chinese who had different political views to those of the Dayaks in ethnically divided Sarawak. The rebels were fighting against the incorporation of Sarawak into the Malaysian Federation, but many Sarawakian Dayaks supported the federation (Van der Kroef 1968a:248). Leaders of the Sarawakian Dayaks were initially reluctant to support the Federation but were persuaded by the Malayan Prime Minister, Tunku Abdul Rahman. Abdul Rahman played on the fear of rising Communism and domination by the Chinese (Said 1985:Chap. 5, particularly pp. 88-90).

${ }_{144}$ The initial success of the rebel attacks was also the result of Communist sympathizers within the army who supplied operational information for the rebels (interview with Djg). Even in the early 1970s, there were still reports of arrests of Communist sympathizers within military ranks in the province (Rachman et al. 1970:274).

${ }_{45}$ S. Jacobus E. Frans Layang, 'Terjadinya PGRS dan Paraku', 22-4-1969', pp. 3-6, in: Collection of S. Jacobus E. Frans Layang, Pontianak.

${ }_{14} 6$ 'Tanggapan dan seruan pemuka-pemuka masjarakat Daya Kalimantan Barat di Pontianak', 31-101967, H.G. Mungok, 'Tjerminkan persatuan dan persatuan demi kekompakan kita semua! Hantjurkan PGRS/Tjina komunis', 3-11-1967', in: Private collection, Sanggau, H.G. Mungok, 'Mukadimah', 5-111967, in: Collection of S. Jacobus E. Frans Layang, Pontianak. The timing of the meeting with leaders from Pontianak district was unclear, but it was probably held before the meeting with leaders from Sambas.

${ }_{147}$ Interview with Smo. 
Commander A.J. Witono, then - because Governor Soemadi was not in his office - met Oevaang Oeray.

Oeray then organized a meeting with this Sambas delegation and more than a dozen Dayak leaders in the Laskar Pangsuma Building in Pontianak. ${ }^{148}$ The document produced after the meeting explained that the rebels had destabilized the security of the province, disturbed the livelihood of the Dayaks and used the Dayak region as the rebel base; the Dayaks had actively helped the military against the rebels by embarking on their own operation against the rebels. In the same document, the Dayak leaders pledged to help the military fight the rebels and welcomed the Dayak willingness to fight. ${ }^{149}$ As a follow-up, Laskar Pangsuma was established with its headquarters in Pontianak City and a detailed organization structure was formed. ${ }^{150}$ Leaders in its headquarters urged Dayaks to form branches in their region. The first to be set up were in the Sambas and Pontianak districts, while eastern district branches were formed later (Davidson 2008:223). In Sanggau the militia was less successful because, according to one former Partindo leader in Sanggau, they did not like the idea of attacking the Chinese. ${ }^{151}$

Oeray believed that most Chinese were helping the Communists, supplying material aid, information and manpower. In his eyes, the Chinese were common farmers by day but guerrillas by night (FEER 21/27-11968). In an interview conducted some time after the conflict, he blamed the Chinese for the conflict (Alexander 1973:4). Because of his position and influence among the Dayaks, his conviction shaped the attitude of

${ }_{14}^{8}$ Interview with Smo. Oeray was absent from this meeting (interview with Smo), although his name was included in a formal statement produced later.

149 They were J.C. Oevaang Oeray, A. Djelani, V. Oendoen, I. Kaping, P. Anjiem, E.D. Tundang, J.A.M. Linggie, H. Tajib, A. Sawa, Joh. Lamid Niga, Asam Djarak, M. Tamzah, Herman Imang Ngo, M. Idris, Atan Palel, D. Nungkad, Nicodemus, David Doengo, Hugo Mungok, M. Kaphat, Sotorman, Ch.E. Jacobus Frans L., L.H. Kadir, St. Ngo Lahay ('Tanggapan dan seruan pemuka-pemuka masjarakat Daya Kalimantan Barat di Pontianak', 31-10-1967, in: Private collection, Sanggau).

${ }_{150}$ A Laskar Pangsuma official document on 5 November 1967 shows a detailed organization structure with a presidium committee, advisory team, secretariat, and eight bureaus. It names virtually all Dayak leaders including members of Partai Katolik such as F.C. Palaunsoeka (H.G. Mungok, 'Mukadimah', 5-11-1967, in: Collection of S. Jacobus E. Frans Layang, Pontianak. The inclusion of Palaunsoeka was probably without his approval, although the involvement of some other Partai Katolik cadres was real. Two of its cadres in the militia, Herman Imang Ngo and Jacobus Layang, for example, were dispatched on a peace mission after the conflict (interview with Lyg). Of all Partai Katolik branches in the province, only the Sambas branch issued a formal statement against the formation of the militia. It was only issued on 18-11-1967, at the winding-up stage of the conflict, perhaps at the direction of the Palaunsoeka who visited the province (Pembangunan, 18-11-1967; Doera 2003:116).

${ }_{15}$ Interview with Omr. 
the militia, as clearly shown by the language used in its pamphlets. In its declaration on 31 October 1967, it blamed the rebels for the instability in the Dayak regions, emphasized the Chinese link to the rebels, and urged the Dayaks to attack. It argued that the Dayaks were merely responding to the Chinese, who were members or logistic suppliers to the rebels. ${ }^{152}$ Another pamphlet on 3 November 1967 used provocative language to urge Dayaks to crush the PGRS/Communist Chinese. ${ }^{153}$

Under the highly charismatic former leaders of PD and Partindo, it was not difficult to mobilize Dayaks to support militia initiatives. Similarly, at the district level a close political connection was found. The chairman of the Sambas Laskar Pangsuma was M. Idris, and the chairman of the Pontianak district militia was Rachmad Sahuddin, both of whom were former Partindo officials in their respective districts. As in many other communal conflicts, the Dayak movements supported by the militia spun out of control. Laskar Pangsuma's instruction issued on the 6 November 1967 ordering the Dayaks to stop the 'demonstration'154 failed to prevent the three bloodiest attacks in Senakin, Darit and Sebadu.

The atrocities in those three towns started to change the local and national perception on the 'demonstration' by the Dayaks. Palaunsoeka, who returned briefly to West Kalimantan, praised the Dayaks for helping the military crush the rebels, but at the same time denounced the killings as racist and indiscriminate (Pembangunan, 10-11, 28-111967). Newspapers blamed the militia for the atrocities, and accused the Communists, such as members of ex-BTI, Partindo, and PKI, of having infiltrated and diverted the popular movement against rebels into racist killings. ${ }^{155}$ According to the newspaper, it was not possible that the Dayaks, who had good relations with the Chinese, would commit such atrocities against them without a mastermind (Pembangunan, 28-11-

${ }_{152}$ 'Tanggapan dan seruan pemuka-pemuka masjarakat Daya Kalimantan Barat di Pontianak', 31-101967', in: Private collection, Sanggau.

153 H.G. Mungok, 'Tjerminkan persatuan dan persatuan demi kekompakan kita semua! Hantjurkan PGRS/Tjina komunis, signed by 3-11-1967', in: Private collection, Sanggau. For example, a witness account accused H.G. Mihing, ex-leader of Partindo, of being a provocateur during the conflict (Doera 2003:124-5).

154 H.G. Mungok, 'Instruksi', 6-11-1967', in: Collection of S. Jacobus E. Frans Layang, Pontianak.

155 Pembangunan, 10-11, 28-11-1967. This accusation was made apparently after the reports of the capture of a few members of the PKI involved in the raids on the Chinese villages. The governor also reported the involvement of a few members of banned leftist organizations ('Pengungsian orang2 Tjina sebagai akibat gerakan2 orang Daya dalam daerah Kabupaten Pontianak dan Kabupaten Sambas', 1967, in: Library of West Kalimantan Governor's Office, Pontianak). 
1967). The newspaper accused the Partindo governor, Oevaang Oeray, of wanting to use the chaos so that he could make a come-back into politics. ${ }^{156}$

As a result of mounting public pressure, within days of the deadly attacks on Chinese, the military claimed to have secured (mengamankan) some masterminds of the attacks. ${ }^{157}$ The military commander also instructed the local population to stop the violent demonstrations. ${ }^{158}$ The Laskar Pangsuma was then put under the control of the local military on 18 November 1967 (Pembangunan, 28-11-1967). A week after that, its leaders were dispatched on a peace mission to the interior regions to calm the Dayaks. The instruction was direct and clear: to tour the district and to help the military defuse the tension. ${ }^{159}$

It is quite apparent that the militia had some roles in the killings in November 1967. At the very least, its provocative pamphlets and the behaviour of its leaders contributed to the atrocities. However, the militia could not have been instigators of the other earlier clashes in October, as it had only been formed in November. It was formed two weeks after the victims had fallen and the refugees had flocked to towns. Some individuals who had been involved in leading the earlier conflicts might have joined the militia at a later time. In this case, it was these individuals rather than the Laskar Pangsuma who were responsible for the attacks. ${ }^{160}$

One can conclude that the 1967 conflict was not as well-planned or orchestrated as some scholars have claimed, although the military welcomed Dayaks' cooperation in opposing the rebels. Military confusion at the local level, as well as the lack of coordination at the top bureaucratic level, indicated a lack of planning. Besides some support from the military, some elite Dayaks and rebels played a part in the conflict. Some

\footnotetext{
${ }_{15}{ }^{6}$ FEER 27-1-1968; Davidson 2008:69. Van Hulten (1992:283) also mentions several goals Oeray wanted to attain from the movements: to free the Dayaks from the economic domination of the Chinese, and to establish a Dayak centre in Anjungan.

157 Pembangunan, 17-11-1967. Unfortunately there were no further reports on the masterminds, but none of the main militia leaders at provincial or district level was arrested, because the military soon sent them to interior regions to appease the angry Dayaks. They probably were local leaders who directly participated in the atrocities and whose names were mentioned in S. Jacobus E. Frans Layang, 'Terjadinya PGRS dan Paraku', 22-4-1969', in: Collection of S. Jacobus E. Frans Layang, Pontianak.

${ }_{15}^{8} \quad$ A.J. Witono, 'Maklumat', 17-11-1967, p. 1, in: Collection of S. Jacobus E. Frans Layang, Pontianak.

${ }_{59}$ 'Surat idzin djalan', 1967, in: Private collection, Singkawang.

160 The late formation of the militia rendered invalid arguments which considered it as the initial instigator of the conflict and massive evacuation that had occurred from the mid to end of October 1967. See such arguments in Davidson (2008:70-1).
} 
elite Dayaks, who wanted to make a come-back into politics, tried to use this opportunity to demonstrate their loyalty to the new regime by fighting rebels and forming a militia. However, they were blamed as the perpetrators of some atrocities at the end of the conflict. The resisting rebels and their successful counterattacks against the Indonesian military created a justification for the army to launch more serious campaigns. Another contributor to conflict was the rising anti-Chinese sentiment as a result of political change at national level.

\section{SUMMARY}

Changes in the political system at the national level had affected Dayak politics. PD, the backbone of Dayak politics, was forced to dissolve after it failed to fulfil one of the new requirements for political parties. Many party members chose to merge with Partindo, a growing nationalist party closely attached to President Soekarno, while a smaller group chose to merge with Partai Katolik. Merger with Partindo had weakened the Dayak politics due to the latter's open and nationalist platform.

When the New Order came to power, Dayak politics was once more under threat. Dayaks who held high posts, such as governor and district heads, lost their jobs. They were members or sympathizers of Partindo, which had become the new enemy of the regime because of its leftist orientation. To salvage the party, its leaders with the approval from the military, merged the party into IPKI, further diminished Dayak political influence. Before the 1971 election, many Dayak leaders were forced to join Golkar. Despite Golkar victory, only a few Dayaks were elected to the parliaments. This minimal representation of the Dayak in the local legislative branch persisted throughout the New Order. Many Dayak bureaucrats also soon found that high positions in the bureaucracy such as district head were no longer attainable.

An opportunity for Dayak leaders to make a political return came about when the regime intensified its campaign to crush the Communist rebels from 1967 onward. During ethnic conflict in 1967, the Dayak leaders openly supported the military campaign against the Communist rebels hoping that this would make a break with their unfavourable political past and enable them to regain government trust. Unfortunately, the Dayaks' political position did not improve, as their contribution in 
the military campaign was blamed for having caused indiscriminate killings of Chinese.

In particular this chapter has again shown that the fate of Dayak politics depended heavily on national politics. When the fortunes of their national ally waned as the regime changed, Dayak politicians at the local level also suffered. 